\title{
Transcending the Individualist Paradigm in Sexual Orientation Antidiscrimination Law
}

\author{
Holning Lau $\dagger$
}

Many businesses restrict their goods and services to opposite-sex couples. These businesses range from travel groups for straight couples only, to ballroom dance studios that require men to dance with women, to photographers who refuse to take pictures of same-sex couples. Recently, these businesses have generated a fair amount of controversy. For example, eHarmony, the popular online dating service, has spawned controversy by refusing to match same-sex couples, claiming that its patented compatibility test is tailored for opposite-sex pairings. ${ }^{1}$ Editorialists, such as Michelangelo Signorile, have accused eHarmony of unjust discrimination. ${ }^{2}$ Sandals, the beachfront resort chain, is another source of recent

Copyright (C) 2006 California Law Rcview, Inc. California Law Rcview, Inc. (CLR) is a California nonprofit corporation. CLR and the authors are solely responsible for the content of their publications.

$\dagger \quad$ Harvey S. Shipley Miller Teaching Fellow, Williams Institute on Sexual Orientation Law \& Public Policy, UCLA School of Law. J.D., University of Chicago; B.A., Univcrsity of Pcnnsylvania. I am grateful for helpful comments from Mary Anne Case, Clarence Cheuk, Melissa Chiang, Kelsi Brown Corkran, Sharon Dolovich, Felicia Ellsworth, Linda Friedlieb, Ran Hakim, Jennie Han, Ken Karst, Zak Kramer, Liz Kukura, Russell Robinson, Brian Rubens, Bill Rubenstein, Seana Shiffrin, and Sarah Sulkowski. I am also grateful for having had the opportunity to present versions of this Essay at workshops run by the University of Chicago's Human Rights Program and by the London School of Economics and Political Science's Human Rights Centre. Of course, errors and omissions remain my own.

1. A former version of eHarmony's website explaincd that "eHarmony does not offer same sex matching services ... [because] cHarmony's research has only examined heterosexual relationships." See Michelangelo Signorile, Point and Lick: What David Brooks Doesn't Know Can't Hurt Him, N.Y. Press, Nov. 11, 2003, at 1 (quoting a former version of eHarmony's website). Although eHarmony has removed the explanation from its website, it still does not offer same-sex matching. See eHarmony, http://www.eharmony.com (last visited Dec. 20, 2005). On the controversial nature of eHarmony's policy, see, for example, Signorile, supra (criticizing eHarmony's policy); Lisa Baertlein, Dating Site eHarmony Has 436 Questions for You, USA TODAY, June 2, 2004, http:/www.usatoday.com/tech/ webguide/intcrnetlife/2004-06-02-eharmony_x.htm (describing eHarmony's policy as controversial).

2. See Signorile, supra note 1; see also Jennifer Hahn, Love Machines, L.A. CITY BEAT, Feb. 10,2005 , at 1 (quoting a commentator: "I don't see [eHarmony's policy] as anything more than rhetoric or an excuse for ... discrimination ... I don't feel that they should be turning anyone away."); Rebecca Traister, My Date with Mr. eHarmony, SAlon.CoM, June I0, 2005, http://www.salon.com/ $\mathrm{mwt} /$ feature/2005/06/10/warren/index.html (noting that the author found it "disturbing" that eHarmony "won't match gays"). 
controversy. Mayor Ken Livingston banned Sandals from advertising in the London Underground because Sandals' romantic getaways only accommodated opposite-sex couples. Subsequently, Sandals volunteered to alter its restrictive policy. ${ }^{3}$

Is criticism against these businesses justified? In the individualist paradigm, ${ }^{4}$ Sandals, under its former policy, may seem no more culpable of discrimination than a retailer that sells only women's bras. The bra retailer has no legal or moral obligation to carry men's underwear or even a bra that fits men. Any individual man can walk into the bra shop, buy a bra, and wear it as he pleases. Similarly, any individual gay man could have accessed Sandals, so long as he brought a female companion. In the individualist paradigm, requiring Sandals to alter its product can be equated with requiring the bra shop to start selling boxer shorts just to accommodate men. In the individualist paradigm, Sandals and the bra retailer seem innocuously similar. ${ }^{5}$

In this Essay, I introduce a theory of couples' aggregate rights, which supports the intuition - held by critics of Sandals and eHarmony-that businesses should not distinguish between same-sex and opposite-sex couples. Numerous moral theorists have persuasively argued that protecting human dignity requires protecting people against discrimination on the basis of sexual orientation. ${ }^{6}$ To take seriously this normative claim against sexual orientation discrimination, jurists must recognize the aggregate moral rights ${ }^{7}$ of couples. Such couples' rights are irreducible to the

3. Press Release, Greater London Authority, Mayor Hails Sandals Decision as Victory Against Discrimination (Oct. 13, 2004).

4. By referring to the individualist paradigm, I am referring to a paradigm in which rights are accorded only to individuals, and individuals are the analytical units among which differentiation is proscribed by antidiscrimination laws. In the couples' rights paradigm that 1 propose below, rights are accorded to both individuals and couples, and both individuals and couples are analytical units among which antidiscrimination laws proscribe differentiation.

5. I elaborate on this point infra, at Part II.D.I., in which I consider the individual's claim against discrimination on the basis of sexual orientation as well as the basis of sex. I also consider the individual's freedoms of intimate association and expression. Ultimately, my analyses highlight the individualist paradigm's shortcomings.

6. See, e.g., Martha C. Nussbaum, Sex and Social Justice 184-2I0 (1999) (offering "a defense of lesbian and gay rights" based on moral philosophy); Nancy Fraser, From Redistribution to Recognition? Dilemmas of Justice in a 'Post-Socialist' Age, 212 New LefT Rev. 68, 77-78 (1995) (discussing members of "despised sexualities" and "the injustice they suffer"). Putting theory to practice, the human rights bodies of the United Nations have endorsed the idea that discrimination on the basis of sexual orientation compromises human dignity. See Holning Lau, Comment, Sexual Orientation: Testing the Universality of International Human Rights Law, 71 U. CHI. L. REV. 1689, 1700-02 (2004) (summarizing the United Nations' position on sexual orientation discrimination). For a counterargument against sexual orientation rights, see John M. Finnis, Law, Morality, and "Sexual Orientation," 69 Notre Dame L. Rev. 1049, I063 (1994) (asserting a "natural law" argument to justify discrimination against sexual minorities).

7. I use the term "moral rights" to refer to rights that derive from moral philosophy as opposed to legal sources. In this Essay, I first propose couples' moral rights by drawing on existing moral 
individual rights of the couple's individual members. In a couples' rights paradigm, eHarmony and Sandals are distinguishable from the hypothetical bra retailer and are more akin to a shop that has a "No Blacks" sign adorning its window. Relying on my theory of couples' rights, I propose a model public accommodations law to govern couple-oriented business establishments. I also highlight the theory's potential implications in other legal contexts, such as privacy and marriage law.

In proposing this theory, I borrow loosely from existing human rights literature that explores ethnic minorities' group rights. The basic premise of group rights - and of the couples' rights I propose - is that an individual's identity is inextricably linked to her memberships in certain social collectives. Accordingly, protecting that individual requires not only protecting her individual right to associate with those collective entities, but also protecting those entities' aggregate rights to develop.

In the context of sexual orientation, the couple and the community are two types of social collectives that shape an individual's sense of self. It follows, then, that three types of sexual orientation rights merit protection: individual rights, couples' rights, and group rights. Between the two types of aggregate rights in this triumvirate-couples' rights and group rights-the former are particularly discussion-worthy because one's sexual orientation classification is necessarily defined by whom she desires to partner with, regardless of whether she identifies with a larger sexual orientation group. ${ }^{8}$ Thus, in this Essay, I focus on couples' rights and leave sexual minority ${ }^{9}$ group rights for a future project.

The remainder of this Essay unfolds in four parts. Part I provides the political backdrop. In light of Lawrence $v$. Texas ${ }^{10}$ and the movement for

theories. I then propose incorporating protections of couples' moral rights into public accommodations laws, thus creating legal rights.

8. In a controversial practice, some people claim cultural and political membership in a gay or lesbian community, but express no desire for same-sex partners. In those cases, group membership shapes the individuals' cultural and political identity, but not their sexual orientation. See Michele J. Eliason \& Kris S. Moran, Lesbians Define Themselves: Diversity in Lesbian Identification, 3 J. GAY LEsbian \& BISEXUAL IDENTITY 47 (1998) (contrasting lesbianism as a political identity with lesbianism as a sexual identity); Patricia A. Cain, Lesbian Perspective, Lesbian Experience, and the Risk of Essentialism, 2 VA. J. Soc. PoL'Y \& L. 43, 66 n.80 (1994) ("Within the lesbian community there has been much debate over the concept of 'political lesbian,' i.e., someone who identifies as lesbian because of her feminist politics, but who is not sexual with women.").

When 1 use the terms "gay" and "lesbian" in this Essay, 1 usc them as they are commonly understood: to refer to homosexuals. In some instances, however, I will distinguish between "homoscxuals" and "gays and lesbians" because not all homosexuals identify with a gay or lesbian community. See Eartha Jane Melzcr \& Steve Koval, Wilson Blocks Boykin From Million More Stage, WASH. BLADE, Oct. 15, 2005, available at http://www.washblade.com/thelatest thelatest.cfm?blog_id=2978 (noting that the civil rights leader Cleo Manago eschews the "gay" label and identifies as "same gender loving" because he does not identify with the gay community).

9. In this Essay, I use the term "sexual minority" as shorthand for "sexual orientation minority," i.e., to refer to all people who do not identify as heterosexual.

10. 539 U.S. 558 (2003). 
same-sex marriage, I address why discussing same-sex couples in the separate context of business establishments matters. In Part II, I lay out the theory for couples' aggregate rights, grounding it in existing literature on aggregate rights. In doing so, I offer a broad definition of "couple"-one that includes long-term partners, short-term partners, and potential partners, such as two people who might meet through a dating service. I also discuss how, as analytical frameworks, individual rights and couples' rights produce disparate legal outcomes. In Part III, I incorporate couples' rights into a model public accommodations law and discuss states of exception, in which couple-oriented businesses should be permitted to maintain a heterosexual (or homosexual) presumption. Finally, in the Conclusion, I summarize this Essay's arguments and highlight their potential implications outside of the public accommodations context.

I

\section{The Backdrop: Sexual Orientation Post-Lawrence}

Amid the present debate over same-sex marriage, it might seem curious that I have chosen to focus my attention not on marriage, but on samesex couples' access to business establishments. Indeed, Andrew Sullivan once suggested that same-sex marriage will be a virtual panacea to the injustices suffered by gays and lesbians. ${ }^{11}$ Does this Essay have its eye on the wrong ball?

This Part provides background on the importance of enabling samesex couples' access to business establishments. Part I.A introduces the public-private dichotomy that has characterized advances in sexual orientation rights. While American law has come to protect the lives of sexual minorities in their own homes, it still underprotects the equality of sexual minorities in public contexts. Part I.B discusses efforts at developing sexual orientation rights in the public sphere. While most of these efforts have focused on marriage, I contend that access to businesses also warrants attention and is best addressed through a couples' rights paradigm.

\section{A. Behind Bedroom Doors:}

\section{Protecting Sexual Minorities in the Private Sphere}

Gay rights advocates rejoiced when the Supreme Court held in Lawrence $v$. Texas that criminalizing consensual same-sex sodomy violated the Constitution's protection of substantive due process. ${ }^{12}$ Some went so far as to describe Lawrence as the "Brown v. Board of gay and lesbian

11. See Andrew Sullivan, Virtually Normal: An Argument About Homosexuality 180-85 (1995) (contending that "[i]f nothing else were done at all, and gay marriage were legalized, ninety percent of the political work necessary to achieve gay and lesbian equality would have been achieved. It is ultimately the only reform that truly matters.").

12. 539 U.S. $558(2003)$. 
America."13 Despite the celebration, however, commentators have noted that Lawrence left something to be desired by focusing so much on the private sphere of same-sex relationships. ${ }^{14}$ In the majority opinion, Justice Kennedy wrote:

[L]iberty gives substantial protection to adult persons in deciding how to conduct their private lives in matters pertaining to sex.... The petitioners are entitled to respect for their private lives. The State cannot demean their existence or control their destiny by making their private sexual conduct a crime.... The Texas statute furthers no legitimate state interest which can justify its intrusion into the personal and private life of the individual. ${ }^{15}$

Lawrence signifies an acceptance of same-sex relations within the private realm. By focusing on the private sphere, however, it falls short of affording sexual minorities what philosophers refer to as a moral right to recognition. Sexual minorities' right to recognition is a right to live visibly non-heterosexual lifestyles while receiving recognition and approval of those lifestyles from other persons. ${ }^{16}$ As philosopher Charles Taylor explained, "Nonrecognition or misrecognition... can be a form of oppression, imprisoning someone in a false, distorted, and reduced mode of being." 17 Tolerance of same-sex conduct behind closed doors does not adequately protect sexual minorities' moral rights. In this regard, Lawrence falls short. Kennedy's opinion invoked the rhetoric of moral rights, holding that the criminalization of same-sex sodomy "demeans the lives of homosexual persons" and subjects them to unwarranted "stigma." However, Lawrence is necessary but not sufficient to protect sexual

13. Laurencc H. Tribe, Lawrence v. Texas: The "Fundamental Right" That Dare Not Speak Its Name, 117 HaRv. L. Rev. 1893, 1895 (2004). See also Katherine M. Franke, The Domesticated Liberty of Lawrence v. Texas, 104 Colum. L. REv. 1399, 1399 n.2 (2004) (listing instances in which commentators bave compared Lawrence to Brown v. Board of Education, 347 U.S. 483 (1954)).

14. See Franke, supra note 13, at 1401-04 (arguing that Lawrence only protected a "privatized liberty"). But see Tribe, supra note 13, at 1948 ("Some argue that Lawrence is merely about decriminalizing closeted consensual intimacies between same-sex partners... This argument, however, seems transparently weak.").

15. 539 U.S. at 572, 578-79 (emphases added).

16. The definition of sexual minorities' right to recoguition, which I offer here, draws on the work of other recognition theorists. See Axel Honneth, Integritv and Disrespect: Principles of a Conception of Morality Based on the Theory of Recognition, 20 POL. THEORY 187, 188-89, 91 (1992) ("[W]e owe our integrity... to the receipt of approval or recognition from other persons.... [Nonrecognition] is injurious because it impairs ... persons in their positive understanding of self-an understanding acquired by intersubjective means.... [Nonrecognition includes] denigration of individual or collective life-styles."); Charles Taylor, Multiculturalism and "The Politics of RECOGNITION" 25-26 (1992) ("Nonrecognition or misrecognition ... can inflict a grievous wound, saddling [people] with crippling self-hatred. Due recognition is not just a courtesy ...[but] a vital human need."). See also Fraser, supra note 6, at 77 ("[T] he injustice [that sexual minorities] suffer is quintessentially a matter of recognition.").

17. TAYLOR, supra note 16 , at 25 .

18. 539 U.S. at 575. 
minorities' moral rights because decriminalizing private conduct fails to eradicate the stigma suffered by sexual minorities in the public realm. Focusing on the private sphere confines sexual minorities' liberty interests to their bedrooms, allowing a heteronormative culture to persist beyond their bedroom doors.

The dichotomous public-private treatment of sexual minorities is not unique to Lawrence. The armed forces" "Don't Ask, Don't Tell Policy"19 is another example. The policy-which prohibits openly gay, lesbian, and bisexual individuals from serving in the forces-suggests that there is nothing wrong with being gay, lesbian, or bisexual, so long as one keeps her sexual orientation private. ${ }^{20}$ Another example arises in asylum law. The law recognizes gays and lesbians as a protected social group for the purpose of asylum claims, ${ }^{21}$ but an immigration judge recently held that asylum should be granted to gays and lesbians only when they are incapable of veiling their sexual orientation in public. ${ }^{22}$ In that case, a Los Angeles immigration judge ordered the deportation of a gay asylum-seeker because "if he returned to Mexico in some [other] community... it would not be obvious that he would be homosexual unless he made that... obvious himself."23 This ruling implies that the asylum-seeker had a duty to suppress his openly gay lifestyle and to confine his sexual orientation to the private sphere.

\section{B. Into the Public Sphere}

Many advocates of sexual orientation rights are hopeful that Lawrence will soon lead to greater rights for sexual minorities in the public sphere.

19. Pub. L. No. 103-160, 107 Stat. 1670 (1993) (codified as amcnded at 10 U.S.C. $\$ 654$ (2000)) (providing for "separation from the armed forces" for "engag[ing] in, attempt[ing] to engage in, or solicit[ing] another to engage in a homosexual act"; for "stat[ing] that [one] is a homosexual or bisexual"; and for "marr[ying] or attempt[ing] to marry a person known to be of the same biological sex.").

20. See Tobias Barrington Wolff, Compelled Affirmations, Free Speech, and the U.S. Military's Don't Ask, Don't Tell Policy, 63 Brook. L. Rev. 1141, 1144 (1997) (discussing how "the Don't Ask, Don't Tell policy permits gay people to serve in the military ... [but also] does more than mandate silence; it compels gay servicemembers to make involuntary and false affirmations of a heterosexual identity that is not their own.").

21. In 1994, Attorney General Janet Reno issued a directive mandating that immigration judges regard homosexuality as a basis for claiming membership in a particular "social group" protected by asylum laws. See Att'y Gen. Order No. 1895-94 (June 19, 1994).

22. See In re Soto Vega, No. A 95880786 (1J L.A. Cal. Jan. 21, 2003), cited in Brief for the Appellant, Soto Vega v. Ashcroft, No. 04-70868 (9th Cir. 2004) (No. 04-70868), available at http://www.lambdalegal.org/binary-data/LAMBDA_PDF/pdf/319.pdf).

23. Press Release, Lambda Legal, Lambda Legal Asks Federal Appeals Court to Grant Asylum to Gay Mexican Immigrant Who Suffered Severe Persecution from Police and Public (Oct. 26, 2004) (quoting the unnamed immigration judge). For additional examples of how the law pressures gays and lesbians to suppress their sexual orientation in the public sphere, see generally Kenji Yoshino, Covering, 111 YALE L.J. 769 (2002). Yoshino discusses demands on gays and lesbians to "pass" (i.e., hide) and to "cover" (i.e., downplay) their sexual orientation in public. Id. at 811-65. 
This hope has manifested itself most visibly in the mobilization for samesex marriage. Indeed, marriage would place a stamp of recognition upon same-sex couples. I contend, however, that focusing on marriage alone is not in sexual minorities' best interests. Instead, advocates of social justice should aIso direct attention at public accommodations, and this Essay offers a new analytical paradigm for doing so.

One problem with focusing exclusively on same-sex marriage is a matter of practicality: the push for same-sex marriage has garnered only marginal success. The Commonwealth of Massachusetts has legalized same-sex marriage, ${ }^{24}$ and San Francisco, New Paltz (New York), and other local jurisdictions issued same-sex marriage licenses for brief periods of time. However, a California court has already invalidated the licenses granted in San Francisco. ${ }^{25}$ Opponents are presently challenging in court the Iicenses issued in other Iocal jurisdictions. ${ }^{26}$ The events in Massachusetts, San Francisco, and New PaItz contributed to a backlash, resulting in thirteen states passing constitutional amendments that ban same-sex marriage and the President proposing a similar amendment on the federal level. ${ }^{27}$ Most recently, in September 2005, the California legislature passed a same-sex marriage bill, which the governor vetoed. ${ }^{28}$

In light of these setbacks, advocates ought to consider additional means of furthering sexual minorities' recognition rights. Laws governing business establishments provide a viable route. Many Iocal public accommodations laws already prohibit discrimination on the basis of sexual orientation, ${ }^{29}$ and some of those laws broadly construe public

24. On November 18, 2003, the Supreme Judicial Court of Massachusetts held that excluding same-sex couples from civil marriage violated the Massachusetts constitution. Goodridge v. Dep't of Pub. Health, 798 N.E.2d 941 (Mass. 2003). On February 3, 2004, the same court, responding to the Massachusetts Senate's request for an advisory opinion, held that civil unions could not substitute marriage for same-sex couples. Opinions of the Justices to the Senate, 802 N.E.2d 565 (Mass. 2004). At midnight on May 16, 2004, the Goodridge opinion went into effect and since then Massachusetts has been issuing same-sex marriage licenses. See Yvonne Abraham \& Rick Klein, Free to Marry: Historic Date Arrives for Same-Sex Couples in Massachusetts, Boston Globe, May 17, 2004, at Al.

25. See Lockyer v. City \& County of San Francisco, 95 P.3d 459 (Cal. 2004); Bob Egelko, Top State Court Voids S.F.'s Gay Marriages, S.F. Chron., Aug. 13, 2004, at A1.

26. See John Caldwell, People of the Year: The Mayors, The Advocate, Dec. 21, 2004, at 34 (summarizing the status of same-sex marriage licenses issued by municipalities).

27. See id. See also Michael J. Klarman, Brown and Lawrence (and Goodridge), $104 \mathrm{MicH}$. L. REv. 431, 459-66 (2005) (discussing the backlash against same-sex marriage, noting contributing factors including the Supreme Court's decision in Lawrence $v$. Texas, legalization of same-sex marriage in parts of Canada, and the events in Massachusetts, San Francisco, and New Paltz).

28. Nancy Vogel \& Jordan Rau, Schwarzenegger Vetoes Same-Sex Marriage Bill, L.A. TIMES, Sept. 30, 2005, at 1 .

29. At the time of this writing, fifteen states and the District of Columbia have public accommodations laws that prohibit discrimination on the basis of sexual orientation: Califomia, Connecticut, Hawaii, lllinois, Maine, Maryland, Massaehusetts, Minnesota, New Hampshire, New Mexico, New Jersey, New York, Rhode 1sland, Vermont, and Wisconsin. CaL. Civ. Code $\S 51$ (Deering 2005) (extended by case law to cover sexual orientation in Curran v. Mount Diablo Council of the Boy Scouts, 195 Cal. Rptr. 325, 338 (Ct. App. 1983)); Conn. Gen. Stat. AnN. § 46A-81C 
accommodations to include everything from public parks to commercial retailers. ${ }^{30}$ Protecting same-sex couples' access to business establishments would be a valuable, intermediate step toward securing same-sex marriagc rights because it would foster visibility-thus positively altering the public perception-of sexual minorities. ${ }^{31}$

Yet despite the existence of public accommodations laws that cover sexual orientation, the laws themselves do not suffice to protect sexual minorities' recognition rights from restrictive business policies. Even though sexual minorities formally have access to business establishments, they are often required to assume pseudonymous heterosexual identities to access those accommodations. Many commercial products and services-such as ballroom dance studios and romantic beach resorts-formally welcome sexual minorities as long as they suppress their sexual orientation and conform to heterosexual norms by coupling with members of the opposite sex. As Cheshire Calhoun once noted, "Unlike 'the love that dare not speak its name,' heterosexuality is the love whose name is continually spoken in the everyday routines and institutions of public social life." ${ }^{, 32}$ Businesses that

(West 2004); D.C. Code AnN. § 2-1402.31 (2001); Haw. Rev. Stat. ANN. § 368-1 (2004) (limited to entities receiving state financial assistance); 775 ILl. Comp. Stat. ANN. 5/1-102 (2001); ME. Rev. Stat. AnN. tit. 5, §§ 4591-94-F (2004); Md. AnN. Code art. 49B, $\$ 5$ (2004); Mass. Gen. Laws AnN. ch. 272, § 98 (West 2000); Minn. Stat. § 363A.08 (2004); N.H. Rev. Stat. ANN. § 354-A:17 (LexisNexis 2005); N.J. STAT. ANN. § 10:5-4 (West 2002); N.M. STAT. § 28-1-2 (2004); N.Y. ExEC. LAW $\S \S 296,296-a$ (McKinney 2005); R.1. GEN. LAws $§ 11-24-2$ (2004); VT. STAT. ANN. tit. 9, $\$ 4502$ (2005); WIS. STAT. ANN. $\S 106.52$ (West 2002). In addition, Nevada's laws declare that sexual orientation discrimination in public accommodations contravenes public policy; however, Nevada does not yet provide a remedy for such discrimination. See Nev. REv. STAT. ANN. $\S 233.010 .2$ (West 2005). Many municipalities have public accommodations laws that protect against sexual orientation discrimination. These cities range from New York City to Lawrence, Kansas. For a table tracking the jurisdictions with public accommodations law covering sexual orientation, see Lambda Legal, Summary of States, Cities, and Counties Which Prohibit Discrimination Based on Sexual Orientation, http:/www.lambdalegal.org/cgi-bin/iowa/news/resources.html?record=217 (last visited on Apr. 21, 2005).

30. See, e.g., CAL. Civ. CodE $\$ 51$ (b) (West 2002) (denoting "all business establishments" as public accommodations); N.J. STAT. ANN. $\S 10: 5-5$ (West 2002) (defining public accommodations to include any "retail shop, store, establishment, or concession dealing with goods or services of any kind.").

31. While greater visibility could possibly lead to increased hostility towards sexual minorities, 1 hypothesize that it would likely improve the public perception of sexual minorities because homophobia is, in large part, a product of ignorance. See Judd Marmor, Overview: The Multiple Roots of Homosexual Behavior, in Homosexual BeHavior, a Modern Reappraisal 19 (Judd Marmor ed., 1980) (explaining that homophobia stems, in part, from ignorance); Gregory M. Herek \& John P. Capitanio, "Some of My Best Friends": Intergroup Contact, Concealable Stigma, and Heterosexuals" Attitudes Toward Gay Men and Lesbians, 22 Personality \& Soc. Psychol. Bull. 412 (1996) (reporting data showing that heterosexuals who interact with gays and lesbians have significantly more favorable attitudes toward gays and lesbians than heterosexuals without such relationships). For a wellarticulated argument that the best road to same-sex marriage is one of incremental reform, see WILLIAM N. Eskridge, Equality Practice: Civil Unions and the Future of Gay Rights (2001).

32. Cheshire Calhoun, Sexuality Injustice, 9 Notre Dame J.L. Ethics \& Pub. Pol'y 241, 253 (1995). 
maintain restrictive policies against same-sex couples are institutions that fit Calhoun's description.

These heteronormative presumptions in business practices prompt the questions: How can public accommodations laws better protect sexual minorities? How can sexual minorities achieve the visibility and recognition that they seek in commercial spaces? Perhaps the lesbian at the ballroom dance competition can wear a rainbow flag to proclaim her pride. A more natural way for the lesbian to convey her identity, however, would be for her to convey her coupling preference. ${ }^{33}$ By protecting diverse couples' aggregate right to access business establishments-instead of focusing on individuals' right of access-this Essay's proposed public accommodations law would provide access to business establishments for sexual minorities qua sexual minorities, instead of sexual minorities masquerading under the guise of heterosexuality.

Whether sexual minorities have a right to access public accommodations as nontraditional couples is a question that carries significant moral weight. Since the heyday of the civil rights movement, many legal scholars have viewed access to public accommodations, including business establishments, as an essential component of citizenship. ${ }^{34}$ The Supreme Court has also recognized that public accommodations laws protect human dignity. Discussing the 1964 Civil Rights Act's public accommodations provision, for example, the Court noted the "deprivation of personal dignity that surely accompanies denials of equal access to public establishments." 35 In light of this precedent, recognition of same-sex couples in business establishments warrants attention along with the lively debate over same-sex marriage.

Increasing the visibility of sanie-sex couples outside of the marriage context is also desirable because it does not implicate all the objections that some queer theorists have launched against same-sex marriage. Michael Warner, for example, argues that same-sex marriage pressures gays and lesbians to become settled, monogamous, gender-conforming, long-term partners who restrict their sex acts to the purely "vanilla"; consequently,

33. Cf. Richard D. Mohr, Gays/Justice: A Study of Ethics, Society, AND Law 236 (1988) ("[A]cting as a couple tends, as much as anything short of saying one is gay, to project one's affectional preferences into the public realm.").

34. See, e.g., Nan D. Hunter, Accommodating the Public Sphere: Beyond the Market Model, 85 MiNN. L. REv. 159I, 1615-17, 1634 (2001) (discussing cultural citizenship, noting that citizenship "is not purely a ereature of the state ... Implicitly, the law has recognized that markets have a role in constituting citizenship. Indeed, public accommodations laws constitute one example of that acknowledgment. Markets seek consumers and thereby bring previously excluded individuals into central social dynamics."); Bell v. Maryland, 378 U.S. 226, 247-55 (1964) (Douglas \& Goldberg, JJ., concurring) (suggesting that discrimination in publie accommodations perpetuates a culture of secondclass citizenship).

35. Heart of Atlanta Motel, lnc. v. United States, 379 U.S. 241, 250 (1964) (quoting the Senate Commerce Committee speaking on the Civil Rights Act of 1964) (internal quotation marks omitted); Roberts v. United States Jaycees, 468 U.S. 609, 625 (1984) (internal quotation marks omitted). 
same-sex marriage further stigmatizes sexual minorities who do not mimic the roles of Ozzie and Harriet. ${ }^{36}$ With the exception of some businessessucn as wedding planners - couple-oriented businesses generally are not as symbolically loaded as the institution of marriage. Protecting same-sex couples' access to business establishments would shine recognition on a broader range of partnerships than does marriage. Moreover, while the government affirmatively encourages marriage by providing married couples with special rights and benefits, the government would not be affirmatively encouraging coupling just by protecting couples' access to businesses. ${ }^{37}$ Thus, protecting couples' access to businesses neither pressures couples to mimic Ozzie and Harriet nor pressures individuals to couple in the first place.

Interestingly, some states, such as Illinois, simultaneously proscribe discrimination on the basis of sexual orientation in public accommodations while explicitly prohibiting same-sex marriage. ${ }^{38}$ This situation creates uncertain dynamics for same-sex couples. If the state will not recognize the same-sex couple through marriage, will it protect the same-sex couple in other aspects of the public sphere? Does Illinois's public accommodations law protect the same-sex couple or only the individual? The remainder of this Essay articulates a theory of couples' moral rights and argues for incorporating protection of those moral rights into a public accommodations law that-unlike Illinois's public accommodations law-clearly protects the couple as a collective entity.

\section{II}

\section{Rights of The Couple}

If a group enjoys a distinct mode of life and if that mode of life takes a collective form, perhaps our moral recognition of that mode of life has to be directed towards the group collectively rather than to its members severally.... [S]ome of what is fundamentally important for people relates to identities that they can possess and to practices in which they can engage only in association with

36. See Michael Warner, The Trouble with Normal: Sex, Politics, and the Ethics of QUEER LIFE 41-80 (1999).

37. "The state not only recognizes marriage, it encourages marriage. Being married is a legal status that entails a broad range of associated rights and benefits for the couple." WILLIAM N. Eskridge, Jr., The Case for Same-Sex Marriage: From Sexual liberty to Civilized Commitment 66 (1996) (emphasis added). See also Chai R. Feldblum, Gay is Good: The Moral Case for Marriage Equality and More, 17 Y ALE J. L. \& FEMINISM 139, 153 (2005) ("The reality today is that society expects that men and women will get married, and those who do not are viewed with pity and in many cases disfavor when they fail to 'achieve' this 'goal."').

38. Compare 775 Ill. Comp. STAT. ANN. 5/1-102 (2001) (prohibiting discrimination on the basis of sexual orientation in public accommodations) with 750 ILL. CoMP. STAT. 5/212(a)(5) (2001) (prohibiting same-sex marriage in the State of Illinois), and 750 Ill. Comp. STAT. 5/213.1 (2001) (declaring same-sex marriage to be against public policy). 
others. Consequently, it can seem merely arbitrary to insist that people can have rights only to goods that they can enjoy individually and never to goods that they can enjoy only collectively. ${ }^{39}$

The moral philosopher Peter Jones had ethnic minorities in mind when he penned the above statement, but its logic lends itself well to the context of sexual minorities ${ }^{40}$ Accepting that justice requires moral recognition of sexual minorities, ${ }^{41}$ one nuust question whether that moral recognition should be directed solely at sexual minorities as individuals.

Throughout this Part, 1 draw loosely on the human rights literature pertaining to ethnic minorities' group rights to develop aggregate rights in the sexual orientation context. 1 discuss aggregate rights generally in Part II.A. In Part II.B, I propose two types of aggregate rights in the sexual orientation context-couples' rights and sexual minorities' group rights-and focus on the former. In Part II.C, I clarify the scope of the term "couple" by delineating three types of entities that merit moral recognition-long-term couples, short-term couples, and potential couples. Finally, in Part II.D, I discuss how the individual rights franework and couples' rights framework produce disparate legal outcomes.

\section{A. Groups and Group Rights}

Western conceptions of rights have largely emphasized the central importance of an individual's right to autonomous self-development. ${ }^{42}$ Recent criticism of the individualist paradigm, however, questions the paradigm's effectiveness in safeguarding human rights and argues that individuals do not develop their notions of self in an abstract vacuum. ${ }^{43}$ This scholarship posits instead that an individual's self-conception is very much informed by her nembership in larger social collectives.

Most existing literature on transcending individualism has focused on ethnic minority groups' cultural rights. ${ }^{44}$ An individual's cultural identity is integral to her sense of self, and an individual's cultural identity can be

39. Peter Jones, Group Rights and Group Oppression, 7 J. Pol. PhIL. 353, 353 (1999).

40. See id.

41. 1 use the term "moral recognition" to refer to recognition that people deserve as a matter of moral rights. On sexual minorities' moral rights to recognition, see supra note 16 and accompanying text.

42. This focus on autonomous self-development grew from Enlightenment-era philosophy. See generally The Age of EnLightenment 1-30 (Lester G. Crocker ed., 1969) (providing an introduction to political philosophy from the Enlightenment). Commentators sometimes use the term "selfdevelopment" interchangeably with "self-determination" and "self-actualization."

43. See Adeno Addis, Individualism, Communitarianism, and the Rights of Ethnic Minorities, 66 Notre Dame L. Rev. 1219, 1246 (1991); Michael Walzer, The Communitarian Critique of Liberalism, 18 POL. THEORY 6 (1990).

44. See, e.g., Will Kymlicka, Multicultural Citizenship: A Liberal Theory of MinoRity Rights (1995). During the past decade, this seminal text propelled much of the discussion of group rights. 
inextricably linked to her membership in cultural groups. ${ }^{45}$ Thus, to protect the individual's right to self-development, ${ }^{46}$ it is imperative to protect the curcural group on wnicn the individual relies to develop her sense of self. Without the larger cultural group, the individual can no longer fully develop herself as an individual.

Before proceeding further with this discussion, it is useful to define "groups" and "group rights." Insofar as moral rights are concerned, groups have a primary defining feature: groups consist of individuals in relations that play a fundamental role in those individuals' self-development. ${ }^{47}$ Thus, members cultivate their identities through the relations they develop in the group. A shift in the intragroup relations changes the group identity and simultaneously alters the identities of the group's individual members. ${ }^{48}$

Ethnic minorities often satisfy this definition of groups. Relations within an ethnic minority group are often fundamental to the individual's affirmation of self. ${ }^{49}$ This affirmative function of an ethnic group grows from the group members' relations with each other-for example, sharing common values with the group, speaking a common language with other group members, or participating in cultural ceremonies. Without these selfaffirming intragroup relations, the individual's sense of self is compromised.

What, then, are moral rights belonging to a group? Drawing from the work of other theorists, I posit that group rights are characterized by three necessary and sufficient components. First, group rights are rights to establish the institutional conditions necessary for the group's development. ${ }^{50}$ Second, in order for a group to have an aggregate right to a particular institutional condition, the request for that condition must grow out of an individual human rights claim. ${ }^{51}$ Third, a group's membership must reach a

45. Id. at 89 .

46. On the right to self-development, see supra note 42 .

47. My definition of groups, based on intragroup relations, draws heavily on Carol Gould's theorizing. See Carol C. Gould, Globalizing Democracy and Human Rights 119-21 (2004); id. at 120 ("1 characterize a social group as an entity constituted by individuals-in-relations.").

48. See Gould, supra note 47 , at 120 (arguing that "a change in these [intra-group] relations would therefore effect a change in the character of the entity itself... [and] the characters of the individuals are transformed by the interactions between them."). Because 1 adopt a relational model of groups, 1 eschew the idea that groups have essential or corporate identities. Cf. Jones, supra note 39 , at 361-64 (discussing the corporate theory to group rights).

49. One should note that the function of group identity is affirmative but not necessarily transformative. Group membership need not transform an individual's sense of self in order to warrant moral recognition.

50. Development should be construed to include both the group's emergence and its continued vitality. This first component of my definition draws on Carol Gould's writing. See Gould, supra note 47 , at 124 ("The group rights that a cultural minority can bear are therefore rights to the cultural conditions for the self-development or transformative activity of its members . . the group can make a valid claim against the majority culture to provide the individuals with these conditions.").

51. Cf. Eric J. Mitnick, Three Models of Group-Differentiated Rights, 35 CoLum. Hum. RTs. L. REv. 215, 217 (2004) ("Colleetive rights... remain legitimate only insofar as they benefit 
critical mass in order to exercise its aggregate rights, and the criteria for this critical mass depend on the rights at stake. ${ }^{52}$

Returning to the example of ethnic minorities will clarify this threepart framework. Consider the assertion that groups have rights to institutional conditions. While an individual has an independent right to exercise her ethnic culture, her ethnic group can make a moral claim for the government to provide institutional conditions that preserve, protect, and legitimize her group's culture, making her exercise possible. Examples include institutionalizing a minority language (e.g., institutionalizing the French language in part of Canada) or allowing a minority ethnic group to govern itself in order to preserve its culture (e.g., institutionalizing limited self-government for Native Americans). ${ }^{53}$ While the government accords these rights to a group, individuals should have standing to speak on behalf of the group to demand enforcement. ${ }^{54}$

Next, consider that the requested institutional conditions must grow out of individual human rights claims. By calling for institutionalized minority language education, groups are appealing to individuals' language rights, which are recognized as human rights. ${ }^{55}$ ln contrast, if a group were to call for laws that allow murder-even if murder is a defining factor of its group identity-it would not satisfy the second component because one cannot make an individual human rights claim to murder.

individuals.") (original emphasis). Most cxisting literature concerning group rights discusses group rights in the context of individuals' cultural rights, which international charters and treaties recognize as universal human rights. See S. James Anaya, On Justifying Special Ethnic Group Rights: Comments on Pogge, in EThNicity AND Group Rights 222-24 (lan Shapiro \& Will Kymlicka eds., 1997) [hereinafter Shapiro \& Kymlicka] (suggesting that, while not all types of groups should have group rights, ethnic groups should because international human rights law protects individuals' cultural rights, which are often related to ethnicity).

52. For background on the critical mass component of group rights (also referred to as the collective or aggregative component of group rights), see Jones, supra 39, at 357-61. But see GoulD, supra note 47, at 119-121 (criticizing the aggregative reading of groups).

53. Native Americans have additional justifications for self-rule, such as the historical fact that Native tribes wcre sovereign entities prior to conquest. However, Native Americans' normative claim to cultural preservation is the justification that is most relevant to this Essay. See Rebecca Tsosie, Tribalism, Constitutionalism, and Cultural Pluralism: Where Do Indigenous People Fit Within Civil Society?, 5 U. PA. J. Const. L. 357, 365 (2003) (explaining that Native Americans can articulate a claim for self-government based on international norms of cultural rights); see also KYMLICKA, supra note 44 at 29-30 (appcaling to multiculturalism to argue for self-government rights of indigenous peoples in North America).

54. I recognize that deciding which individuals should have authority to speak for a group can bc a difficult question-one which I cannot address adequately within the scope of this Essay. For a related article, see William B. Rubenstein, Divided We Litigate: Addressing Disputes Among Group Members and Lawyers in Civil Rights Campaigns, 106 Y ALE L.J. 1623 (1997).

55. Intcrnational human rights treaties protect individuals' rights to speak any language of their choosing. See, e.g., International Covenant on Civil and Political Rights, art. 2, para. 1, Dec. 19, 1966, 999 U.N.T.S. 172 (forbidding state parties from discriminating on the basis of, inter alia, language); International Covenant on Economic, Social, and Cultural Rights, art. 2, para. 2, Dec. 16, 1966, 993 U.N.T.S. 4 (providing the same). 
Finally, consider the collective component of group rights. Although there is no bright line for critical mass, the principle dictates that a group must have enough members for implementation of the institutional conditions to be feasible. For example, minority language education is feasible only if there are enough affected students to sustain such a school system. Ethnic minorities often satisfy critical mass and also articulate moral claims for institutional conditions based on individual human rights, thus voicing valid claims to group rights.

What are the dynamics between group rights and individual rights? By their nature, the rights are intertwined. Group rights derive from the principle of individual self-development; however, they are not reducible to the rights of individuals. For example, an individual qua individual cannot demand self-government for herself only. But individuals can speak on behalf of their group. Thus, an individual Native American can assert a moral claim on behalf of her tribe, such as the moral claim to institutionalize Native American self-rule. ${ }^{56}$ Though the individual has a right to associate with other tribe members and exercise tribal culture, those individual rights are not synonymous with the group's aggregate right to selfgovernment.

I should note here that some aspects of group rights are controversial. A debate exists over how to manage points of tension between group rights and individual rights. ${ }^{57}$ Consider the tension that arises when an ethnic group invokes culture to oppress women, and when a group invokes cultural practices that compromise human rights of non-group members. To the extent that these tensions carry into the couples' rights context, they can be managed through mechanisms discussed below. ${ }^{58}$

\section{B. Aggregate Rights in the Sexual Orientation Context}

In light of the group rights framework, 1 contend that individuals' sexual orientation rights are interrelated with the aggregate rights of both couples and sexual minority communities. As a starting point, I accept an argument moral philosophers have previously articulated, which is that people should have the freedom to develop their self-understanding of sexual orientation without subjection to discrimination because such

56. For more on the entanglement between individual rights and group rights, see Jones, supra note 39 , at $354-55$.

57. For a discussion concerning the points of tension between group rights and individual rights, see KYMLICKA, supra note 44, at 34-48.

58. On mechanisms for dealing with the tension between individual rights and aggregate rights, see infra note 78; infra Part III.B.3. A debate also exists on whether group rights should be considered human rights or rights by some other name. As this debate is only tangentially relatcd to the topic at hand, I will not explore it in this Essay. However, for background, see generally Peter Jones, Human Rights, Group Rights, and Peoples' Rights, 21 HuM. RTs. Q. 80 (I999) (defending group rights as human rights). 
discrimination compromises human dignity. ${ }^{59}$ Although some philosophers dissent on this point, ${ }^{60}$ the idea has begun to achieve legitimacy in practice. For example, the international human rights regime has adopted a sexual orientation antidiscrimination principle. ${ }^{61}$

Theorizing a principle of sexual orientation antidiscrimination first requires an understanding of what constitutes a sexual orientation. One's sexual orientation is necessarily characterized by the partner with whom she desires to associate. ${ }^{62}$ Membership in a particular type of couple can affirm an individual's sense of self, including her sense of sexual orientation. ${ }^{63}$ Under this logic, couples are collective entities that should be accorded moral rights. Rights should also be accorded to larger social groups, such as the gay community; however, I will not theorize those group-level rights in this Essay. ${ }^{64}$ Defining sexual minority groups and their respective rights involves complexities that warrant consideration in a separate project. ${ }^{65}$ Indeed, in discourse on scxual orientation, scholars disagree on how to define particular minority groups. Commentators have clashed, for

59. For examples of philosophers who have made this claim, see supra note 6 .

60. See, e.g., Finnis, supra note 6 (asserting a "natural law" argument to justify sexual orientation discrimination).

61. For background on the United Nations human rights bodies' stance on sexual orientation, see Lau, supra note 6.

62. I do not mean to suggest that individuals must couple to develop a full sense of sexual orientation. The desire of partnering itself shapes one's notion of sexual orientation and some individuals may be able to fully develop that sense without ever interaeting with an actual partner. However, those cases do not belie the fact that, as discussed below, many people do rely on interactions to cultivate their sense of sexual orientation and thus suffer a wound when people direct diserimination at couples. Similarly, even though some people can fully develop their cultural identity without associating with a defined ethnic group, ethnic groups still warrant protections.

63. In this Essay, I focus on the fact that membership in a couple affects one's sense of sexual orientation. I do recognize, however, that membership in a couple affects personal identities in additional ways. For the present, I focus on the sexual orientation component of identity because it most directly relates to the legal topic at hand, i.e., sexual orientation antidiscrimination law.

64. I am open to the possibility that polyamory may be a defining element of some individuals' sexual identity and, thus, polyamorous unions may warrant some types of aggregate rights. However, for the purposes of my current project on business establishments, I leave the question of polyamory for another day because, without further research, it is unclear how feasiblc it would be to require business establishments to provide equal access for couples, threesomes, foursomes, etc. Consider the difficulty that would arise in determining how big a Sandals room must be to accommodate larger collective entities. Cf. Mary Anne Case, Marriage Licenses, 89 MiNN. L. Rev. 1758, 1783-84 (2005) (distinguishing same-sex marriage from polygamy based on functional-but not moral-reasons). Additionally, based on existing theoretical literature, it is unclear whether the orientation and numerosity components of sexual identity warrant identical degrees of moral recognition. For a thoughtful defense of polyamory, see Elizabeth F. Emens, Monogamy's Law: Compulsory Monogamy and Polyamorous Existence, 29 N.Y.U. Rev. L. \& Soc. Change 227 (2004).

65. Some commentators have already begun to frame gay and lesbian rights as group rights. See, e.g., William F. Felice, Taking Suffering Seriously: The Importance of Collective Human Rights 46-47 (1996) (“[1]esbian and gay rights are group rights"); IRIS MARION YounG, JusTICE AND THE Politics of Difference 160-61 (1990) ("Today most gay and lesbian liberation advocates seek not merely civil rights, but the affirmation of gay men and lesbians as social groups with speeific experiences and perspectives."). 
example, on what it means to be gay. Is gay identity a social construction, political construction, biological category, or all or none of the above? ${ }^{66}$ Should we do away with the term "gay" and employ instead a classification system modeled on the Kinsey six-step scale? ${ }^{67}$ Can a man occasionally perform oral sex on other men but not identify as gay or bisexual? ${ }^{68}$ These are all questions that scholars continue to debate.

While there is disagreement over how to categorize different sexual minority groups, little disagreement exists over the definition of sexual orientation itself. According to the American Heritage Dictionary, sexual orientation is the "direction of one's sexual interest towards members of the same, opposite, or both sexes," 69 and it seems that this definition is widely accepted. In reading this definition, one should interpret "sexual interest" liberally, understanding that "sexual interest" need not directly relate to sexual acts. Our sexual interests echo in various aspects of our lives. Sexual interests define whom we want to date, before whom we feel comfortable appearing nude, whom we view as potential life partners, even whom we wish to twirl and dip on the ballroom dance floor.

Based on this definition, one's sexual orientation is necessarily relational. ${ }^{70}$ Although an individual's sexual interests are internal, those interests are directed at the external: other individuals. The interpersonal bonds that arise from one's sexual interests are integral to one's sense of her sexual orientation. ${ }^{71}$ Accordingly, couple status satisfies the

66. For background on the debates over defining sexual identities, see NrkKI SULLIVAN, A Critical Introduction to Queer Theory $37-98$ (2003). See also Wayne Brekhus, Peacocks, Chameleons, and Centaurs: Gay Suburbia and the Grammar of Social Identity (2003) (presenting an ethnographic study illustrating that gay individuals express their gay identities in different ways, not necessarily subscribing to so-called gay culture).

67. The Kinsey scale measures an individual's sexual orientation from zero (exclusively heterosexual) to six (exclusively homosexual) based on the individual's past sexual experiences. See Alfred C. Kinsey et al., Sexual Bemavior in the Human Male (1948).

68. See, e.g., Janis S. Bohan, Psychology and SeXual Orientation: Coming to Terms 1417 (1996) (noting cultures, including Melanesian and African, in which same-sex sexual activity is considered a rite of passage for individuals who identify as heterosexual).

69. American Heritage Dictionary of the English Language (Houghton Mifflin, 4th ed. 2000). See also Francisco Valdes, Queers, Sissies, Dykes, and Tomboys: Deconstructing the Conflation of "Sex," "Gender," and "Sexual Orientation" in Euro-American Law and Society, 83 CALIF. L. REV. 1, 23 (1995) (referring to "sexual orientation" as "the apparent or actual inclination(s) of sexual or affectional interests or desires among humans toward members of the same sex, the other sex, or both sexes.").

70. See Mary Anne Case, Couples and Coupling in the Public Sphere: A Comment on the Legal History of Litigating for Lesbian and Gay Rights, 79 VA. L. REV 1643, 1650 (1993) ("At some point, it seems, almost definitionally, coupling or the desire to couple must figure in same-sex orientation. In the words of the adage, 'It takes two women to make a lesbian."').

71. See Brief of Amici Curiae Am. Psychol. Ass'n et al, at 4-5, Lawrence v. Texas, 539 U.S. 558 (2003) (No. 02-102) [hereinafter APA Brief] ("Sexual orientation is therefore integrally linked to the close bonds that human beings form with others to meet their personal needs for love, attachment, and intimacy. These bonds also encompass nonsexual physical affection between partners, shared goals and values, mutual support, and ongoing commitment. Because of the fundamental and identity-defining character of these bonds, sexual orientation is closely related to important personal identities ...."). 
individuals-in-relations characterization of groups, which begs the question: should couples have aggregate moral rights? Extending the group rights analogy suggests the answer is yes.

Moral recognition of same-sex couples is as important to sexual orientation rights as moral recognition of groups is to cultural rights. Couples ought to have aggregate moral rights because couples satisfy the three requirements for group rights. First, couples can claim aggregate rights to institutional conditions that protect their development. One such condition is legal protection of couples' equal access to business establishments. Second, this claim grows out of the human rights principle against sexual orientation discrimination. Third, the critical mass component falls to the wayside because the couples' rights that 1 propose in this Essay are rights to nondiscrimination. The typical rights claim would involve same-sex couples asking for access to existing goods and services that are tailored for couples. The critical mass required for enjoying these products is twoa number that same-sex couples satisfy by definition. This scenario differs from the cases where a minority cultural group needs to amass a certain number of people to make institutional conditions such as self-government or second-language education feasible.

The analogy between moral recognition of groups and of couples is compelling. In the cases of both groups and couples, recognizing the moral rights of the collective entities produces results that cannot be achieved in the individualist paradigm. ${ }^{72}$ Yet the analogy between ethnic groups' cultural rights and couples' right to nondiscrimination is imperfect. In my view, the aggregate right to nondiscrimination belonging to couples is, in some regards, more appealing than ethnic minorities' aggregate cultural rights. Specifically, the degree of tension between individual and group rights does not transfer to the relationship between individual and couples' rights. ${ }^{73}$ Some theorists fear that groups might invoke group rights to oppress subgroups or individuals within the group. For example, a group might invoke its culture as a defense to charges that it oppresses women. While oppressive couples certainly exist ${ }^{74}$ it is substantially easier to exit an oppressive couple than an oppressive ethnic group. ${ }^{75}$ A no-fault divorce is much easier to obtain than a change of ascriptive, physical characteristics - characteristics that might lead people to identify an individual as an

72. See infra Part II.D for a discussion contrasting these disparate outcomes.

73. For background on the tension between group rights and individual rights, see KYML.1CKA, supra note 44, at 34-48; Jones, supra note 39, at 368-77.

74. For example, physical violcnce, psychological abuse, and patriarchal norms between partners can all contribute to a couple's opprcssiveness.

75. I recognize that there are significant hurdles to exiting an oppressive couple. These hurdles are illustratcd, for example, by the situations faced by many battered women. See Martha R. Mahoney, Legal Images of Battered Women: Redefining the Issue of Separation, 90 MicH. L. REv. 1, 61-71 (1991) (describing battered women's decisions to stay in abusive relationships as a reasonable responsc to the constraints on exit including the risk of assault that aceompanies exit). 
ethnic minority, even if that individual did not so self-identify. Indeed, the highly voluntary nature of coupledom mitigates the tension between group and individual rights. ${ }^{76}$ Some theorists also fear that dominant groups might invoke group rights to oppress outside individuals and groups. Again, this fear should not transfer to the context of couples. As collectives of only two people, couples wield neither the size nor power that is likely necessary to oppress people outside of the couple. ${ }^{77}$

Although couples' rights do not conflict with individual rights, they sometimes conflict with group rights. For example, a group might argue that, because same-sex relationships violate its religious beliefs, it should be allowed to treat opposite-sex and same-sex couples differently. But to the extent that couples' and group rights present competing interests, they can be balanced in the fashion that competing individual and group rights are already balanced. ${ }^{78}$ Existing mechanisms for such balancing are discussed in Part III.B.3.

Notably, government protection of couples' right to intimacy does not provide sufficient institutional conditions for couples to develop. Social scientists have concluded that the "identity-defining" bonds between members of a couple develop not only from sex, but also from "nonsexual physical affection between partners, shared goals and values, mutual support, and ongoing commitment." 79 These bonds are most often developed outside the confines of the bedroom. Thus, recognition of couples' rights should extend into the public sphere. ${ }^{80}$

One might wonder where to draw the line between couples and other types of associations. A failure to draw a line would stretch the right to

76. One might query whether the voluntary nature of coupledom undermines the need to protect couples. 1 believe Thomas Pogge was correct when, in discussing group rights, he argued that "there are strong reasons against ... making politically significant a distinction between inherited and chosen cultural identities." Thomas G. Pogge, Group Rights and Ethnicity, in Shapiro \& Kymlicka, supra, note 51 , at $210-212$.

77. Certainly, some couples oppress their children. However, such oppression does not stem from the fact that the parents are coupled; single parents are often liable for oppressive parenting.

78. Consider the Supreme Court's balancing of groups' expressive rights and individuals' rights to nondiscrimination in cases such as Boy Scouts of America v. Dale, 530 U.S. 640 (2000) and Roberts v. United States Jaycees, 468 U.S. 609 (1984). In Dale, the Boy Scouts' expressive rights trumped a gay seoutmaster's right to nondiscrimination. In Roberts, the state's interest in protecting women from discrimination trumped the Jaycees' expressive rights.

To the extent that existing balancing schemes are flawed, the goal should be to recalibrate the scales (a project that I save for a future discussion). The tension between individual and group rights does not necessitate the wholesale abandonment of either type of right. See Peter Rosenblum, Teaching Human Rights: Ambivalent Activism, Multiple Discourses, and Lingering Dilemmas, 15 HARv. Hum. RTS. J. 301, 306-08 (2002) (noting the tension between individual and group rights, but maintaining that both types of rights are legitimate and that both should inform the development of human rights law).

79. APA Brief, supra note 71, at 5 .

80. Axel Honneth theorized that "dignity... [requires] social acceptance fortheoming for a person's method of self-realization." Honneth, supra note 16, at 191. In that logic, membership in a couple is a "method of self-realization" that warrants public recognition. 
self-development to an unwarranted extreme. Plenty of personal associations influence people's self-development. Camaraderie with one's softball teammates might be a formątive component in one's selfdevelopment. Should the team be afforded aggregate rights? Despite sharing a superficial parallel, couples and other forms of association, such as softball teams, are distinguishable by the second component of group rights. ${ }^{81}$ Freedom from sexual orientation discrimination is an essential element of an individual's human dignity. Conversely, membership in a softball team, while it may shape an individual's sense of self, does not implicate dignity in the way sexual identity does. ${ }^{82}$

Finally, 1 should reemphasize that 1 am arguing to have couples' rights supplement-not supplant-individual and group rights. 1 envision a place for all three types of rights in sexual orientation antidiscrimination law, which would protect, for example, an individual lesbian's right to non discrimination in employment, a couple's rights of equal access to public accommodations, and a gay community's right to congregate in places such as bars. ${ }^{83}$

\section{Long-term Couples, Short-term Couples, Potential Couples}

If we accept that couples deserve moral recognition as a collective entity, how should the status of "couple" be defined? Should couples be defined by a formal demarcation, for example a minimum time period of dating or registration of some sort? Would Sandals' ban on same-sex couples have been less offensive to London Mayor Livingston if the company made an exception for married same-sex couples? Can one justify Michelangelo Signorile's criticism of eHarmony from a couples' rights standpoint, considering that eHarmony is not discriminating against existing couples but just choosing what types of couples it brings together? Where should the moral theorist draw the line?

ln my view, taking sexual orientation justice seriously means recognition must be liberally shone upon not only long-term couples, but also short-term couples, and even potential couples. The basis for my capacious construal of coupledom is the fact that couples' moral rights derive from the principle of self-development. One develops her sexual identity through

81. The second component dictates that group rights must share a nexus with individual human rights claims. See supra note $5 \mathrm{I}$ and accompanying text.

82. Five United Nations human rights treaty bodies have declared that protection from discrimination on the basis of sexual orientation is a human right. See Lau, supra note 6 , at $1702 \mathrm{n} .84$ (collecting United Nations statements and opinions on sexual orientation discrimination). There have been no similar statements regarding discrimination on the basis of membership in sports teams. Likewise, moral philosophers have articulated a relationship between sexual orientation and human dignity. See supra note 6.

83. In the early to mid-twentieth century, many states rescinded liquor licenses from bar owners who allowed gays to congregate at their bars. On the regulation of gay bars, see WILLIAM N. ESKRIDGE, JR., Gaylaw: Challenging the Apartheid of the Closet 44-46, 78-80 (1999). 
her personal associations. Long-term relationships, short-term relationships, and even relationships in the abstract significantly shape one's sexual identity. Limiting moral recognition to long-term relationships also seems objectionable because some queer theorists articulately challenge conventional, monogamous, long-term relationships for being relics of regressive heteronormativity. ${ }^{84}$

In speaking of "short-term" couples, I am referring to couples that have maintained a bond for only a short time span. It might be two people who have dated for only two months, but want to escape to a Sandals romantic resort together. It might even be two people who pair up at ballroom dancing lessons. They may be no more than dance partners for the class; however, affirmation of their sexual orientation will still come into play. To any given individual, dancing with a partner of one sex or another might feel particularly natural or particularly awkward. Even when ballroom dance partners are not sexual partners, the couple-oriented nature of a ballroom dance can affirm - or suppress - the sexual identity of the dance partners who become, even for a moment, a couple entitled to moral recognition. ${ }^{85}$

In speaking of "potential" couples, I am referring to entities implicating dating services such as eHarmony, which target romantically unattached individuals with the business goal of creating (short- or long-term) couples. In dating situations, individuals view themselves as one half of a potential couple. eHarmony's clients, no less than the members of longand short-term couples, are individuals-in-relations because they affirm their own-and each other's-sense of self by offering to serve as one another's potential partners. Although the couple exists only in an abstract sense, the individual's feeling of belonging to a potential couple still affirms her sense of identity. Accordingly, the individual has a claim to moral recognition of that potential collective entity. As in the cases of long-term and short-term couples, an individual constituent of a couple-indevelopment can still put herself forth and speak for the potential collective.

When a dating service refuses to match same-sex couples, it is discriminating between same-sex and opposite-sex couples by not recognizing the validity of the former. To borrow language from constitutional jurisprudence, the business is subjecting two types of potential entities (opposite-sex couples and same-sex couples) to disparate treatment. The business

84. See, e.g., WARNER, supra note 36 , at 41-80.

85. Cf. Eric Marx, In the Ballroom, a Redefinition of "Couple, "NY Times, Jul, 14, 2004, at E1 ("[1]f questions of gay identity and inclusion are being engaged in the workplace and in the bonds of marriage, then why not in [a] professional and amateur sport [such as ballroom dance]?"); Wyatt Buchanan, Ice Rink Settles Gay Discrimination Suit, S.F. CHron., May 1 1, 2006, at B3 (reporting that two men sued an ice rink for prohibiting them from skating together and describing how the lawsuit ended in settlement). 
is not subjecting individuals to disparate treatment: as a formal matter, individual gay men, lesbians, and bisexuals have equal access to the dating service. However, such disparate treatment creates a disparate impact on individuals of different sexual orientation (bisexual, gay, and straight). Ultimately, because the disparate treatment is directed at a type of couple, remedying the injustice requires shining recognition on that type of couple-even though it is a "potential" couple.

One can compare matchmaking services to educational institutions. At first glance, the comparison appears to be a stretch, but closer examination suggests that the analogy is worth some consideration. Matchmaking services enable coupled identities while educational institutions enable group identities. Refusing to teach a minority child how to read her native language inflicts injury on the child even if she is merely beginning to learn how to read. The child is only in the process of realizing her potential as a member of a cultural collective, but the process of developing membership is as worthy of recognition as the membership status itself. By enabling one language and not another, an educational institution discriminates; whether that discrimination is normatively justified will depend on the feasibility of minority-language instruction. Similarly, by enabling one type of coupled entity and not another, matchmaking services discriminate.

Non-recognition of potential couples can be as injurious as nonrecognition of short-term and long-term couples. Considering the historical subordination of sexual minorities, the public might infer-correctly or incorrectly-that a business refusing to match same-sex couples has chosen to do so because same-sex couples are in some way inferior. It is precisely this false inferiority and consequent stigmatization that recognition rights are supposed to ameliorate. Thus, recognition should be directed not only at concrete couples, but also at couples-in-development.

\section{From Moral Rights to Legal Rights}

The law can be used to protect couples' aggregate moral rights. In this Essay, I focus on one potential form of legal protection: laws that protect couples' equal access to commercial establishments. Building on the group rights analogy, couples' rights are rights to institutional conditions that protect couples' development. Nondiscrimination in commercial spaces is one such institutional condition.

Discrimination against a couple can impede that couple's development in at least two regards. First, discrimination is a deprivation of recognition. ${ }^{86}$ Even if a business does not exclude two individuals severally, those individuals suffer a wound when they are members of an excluded

86. Sexual minorities' right to recognition is a right to live visibly non-heterosexual lifestyles while receiving recognition and approval of those lifestyles from other persons. On recognition rights, see supra notes 16-17 and accompanying text. 
type of couple. Exclusion suggests that the business refuses to recognize the couple's legitimacy, striking a blow at the couple's collective dignity and self-respect. ${ }^{87}$ Those dignitary harms burden the couple's development. Second, exclusion deprives the couple of tangible goods and services that might nurture the couple's development.

In the reinainder of this Part, I show how laws in the individualist paradigm under-protect couples' access to commercial establishments. Accordingly, I sketch an alternative legal framework based on couples' aggregate rights.

\section{Existing Antidiscrimination Law: Why the Individualist Paradigm Does Not Suffice}

Construed in the individualist paradigm, antidiscrimination laws under-protect couples. By using the term "individualist paradigm," I am speaking of a paradigin in which rights are accorded only to individuals and individuals are the analytical units among which differentiation is proscribed by antidiscrimination laws. In this paradigm, couple-oriented businesses that maintain a heteronormative presumption do not discriminate against sexual ininorities because the businesses are not differentiating among individuals. ${ }^{88}$

87. On the dignitary harm of exclusion, see Heart of Atlanta Motel, Inc. v. United States, 379 U.S. 241, 250 (1964) (noting "the deprivation of personal dignity that surely accompanies denials of equal access to public establishments.") (internal quotation marks omitted); Catriona McKinnon, Exclusion Rules and Self-Respect, 34 J. VALUE INQUIRY 491, 491, 494-97 (2000) ("[T]he exclusion from membership of some people by others prima facie damages opportunity for self-respect for the excluded."). Although McKinnon discussed exclusion from social groups, one can apply her theorizing to exclusionary policies more generally. On the notion of collective dignity, see Rhoda Howard, Dignity, Community, and Human Rights, in Human Rights in Cross-Cultural Perspective 84 (Abdullahi An-Na'im ed., 1992) ("[H]uman dignity is not private, individual, or autonomous. It is public, collective, and prescribed by social norms."); Law v. Canada, [2003] 1 S.C.R. 497, 953 (Can.) ("Human dignity means that an individual or group feels self-respect and self-worth.") (emphasis added).

88. The limited-but growing-case law on this question is unhelpful. In one case, Rolon v. Kulwitzky, 153 Cal. App. 3d 289 (Ct. App. 1984), a lesbian couple successfully brought a discrimination claim against a restaurant that refused to seat same-sex couples in semi-private booths reserved for couples. Unfortunately, the case's conclusory three-page opinion offers little analysis. By explicitly adopting a theory of couples' rights, the court would have strengthened its seemingly intuition-based opinion. In the contrasting case of Engel v. Worthington, 23 Cal. Rptr. 2d 329 (Ct. App. 1993), a photographer refused to photograph same-sex couples. In Engel, the court found sex discrimination, but no sexual orientation discrimination. Id. The opinion was eventually withdrawn by order of the court. Engel v. Worthington, No. S036051, 1994 Cal. LEXIS 558 (Cal. Feb. 3, 1994). Finally, there is a pending California case in which same-sex couples are suing an adoption-related business for refusing to post the couples' profiles on its website. Butler v. Adoption Media, LLC, No. C 04-0135 PJH, 2005 WL 1513142 (N.D. Cal. June 21, 2005) (establishing jurisdiction for the case).

The question at hand is not specific to the United States. At least one expert on European Union law laments his belief the European Court of Justice will likely determine that discrimination against same-sex couples does not constitute sexual orientation discrimination. See Bruce Carolan, Judicial Impediments to Legislating Equality for Same-sex Couples in the European Union, 40 TULSA L. REV. 527, 528-30 (2004). 
A lesbian woman could have stayed at a Sandals resort under the company's former guest policy. The only condition was that she conform to Sandals' heteronormative culture and bring along a male travel buddy. Similarly, a gay man can access eHarmony's dating service, but he must use the dating service to meet women. Thus, as a formal matter, these businesses are not differentiating between gay and straight individuals. They are welcoming all individuals so long as each individual conforms to their norms. ${ }^{89}$ This individual rights analysis appears unsatisfactory once one realizes that, in the context of sexual orientation-which is necessarily relational-the individual's identity cannot be disaggregated from the couple's identity.

The couples' rights paradigm can overcome this shortcoming. In the couples' rights paradigm, rights are accorded to couples and couples are analytical units among which differentiation is proscribed by antidiscrimination laws. ${ }^{90}$ Therefore, existing laws proscribing sexual orientation discrimination would be interpreted to proscribe discrimination between same-sex and opposite-sex couples, even absent discrimination among individuals. Some foreign courts have already adopted this rationale. ${ }^{91}$ Future

89. Contrast this scenario with cases in which businesses violated public accommodations laws by saying "No Blacks"; in those cases, the blacks could not access the business establishments even if they were willing to conform to white norms. See, e.g., Lewis v. Doll, 765 P.2d 1341, 1342 (Wash. Ct. App. 1989) (finding a violation of a public accommodations law where a 7-11 clerk stated to a black man: "No, we have a policy. Boss left strict orders not to serve any blacks . . 1 don't serve any blacks."); Ledsinger v. Burmeister, 318 N.W.2d 558, 560 (Mich. Ct. App. 1982) (finding a violation of a public accommodations law where a store owner told a black couple that he "did not want or need nigger business"). Also, contrast the scenario with cases of sex discrimination, in which women could not access a public accommodation no matter how masculine they acted. $C f$. Roberts v. United States Jaycees, 468 U.S. 609 (1984) (finding a violation of a public accommodations law where an organization restricted membership based on sex but not gender).

90. Note that my definitions of individual and couples' rights focus on how rights are distributed as opposed to how rights are exercised. While 1 argue that rights should be accorded to couples, an individual sbould have standing to make arguinents based on eouples' rights. This formulation follows from the notion that an individual can have standing to demand group rights, such as a right to minority-language education for an ethnic minority group. Cf. Will Kymlicka \& Ian Shapiro, Introduction, in Shapiro \& Kymlicka, supra note 51, at 4 (discussing ethnic minorities' group rigbts, opining that "[f]ocusing solely on whether the rights are exercised by individuals or groups misses what is really at issue ....").

91. For example, in finding that barring same-sex couples from marriage violated the Canadian constitution, the Ontario Court of Appeal repeatedly appealed to "couples' equality rights." Halpem v. Toronto, 172 O.A.C. 276 (2003). The reasoning in Halpern suggests the court used the term "couples' equality rights" to refer to an aggregate right vested in the couple. The court stated that assessing the existence of discrimination required a comparison not of individuals, but of same-sex and opposite-sex couples. See id. at fi] 65-72. It also stated that "[h]omosexual couples as well as hounosexual individuals have suffered greatly as a result of discrimination ... homosexuals, wbether as individuals or couples, form an identifiable minority." Id. at If 83 (quoting Egan v. Canada, [1995] 2 S.C.R. 513, If 184 (Can.) (Cory, J., dissenting). See also EGALE Canada lnc. v. Canada, 182 B.C.A.C. 35, 忖 133-35 (2003) (discussing "equality rights of same-sex couples" and citing Halpern with approval).

Similarly, in its landmark saine-sex marriage case, the South African Constitutional Court stated that discrimination is unacceptable regardless of whether it is directed at gays and lesbians "viewed as individuals or in their same-sex relationships." Lesbian \& Gay Equality Project v. Minister of Home 
laws should adopt the couples' rights paradigm by explicitly proscribing discrimination among types of couples. The following Part introduces a model law for doing so.

A strict proponent of individual rights who favors realism over formalism may advocate expanding the scope of individual rights rather than supplementing them with couples' rights. ${ }^{92}$ For example, existing public accommodations laws generally prohibit businesses from discriminating against potential patrons by withholding access, thus creating a right of access. ${ }^{93}$ A realist might propose that, instead of protecting couples' aggregate right to access Sandals, existing laws should be reinterpreted to protect individuals' meaningful access of Sandals. Put differently, the realist might argue that public accommodations laws should protect substantive equality, not formal equality..$^{94}$

I believe that claims to substantive equality have strong moral force. However, morally sound claims do not always map easily onto legal rights. ${ }^{95}$ This is particularly true in the context of public accommodations law. In legal practice, protecting an individual's meaningful access is problematic because "meaningful" is vague and subjective. If the law required

Affairs, [2005] (1) SA 04 (CC), ๆ 50 (S. Afr.), available at http://www.constitutionalcourt.org.za/site/ gaylesb.htm (emphasis added). The court also invoked the "right to dignity of same-sex couples." Id. at if 57.

92. Courts are sometimes extremely reluctant to take a realist approach to antidiscrimination law. For example, the Supreme Court has twice held that pregnancy discrimination does not amount to sex discrimination. General Electric Co. v. Gilbert, 429 U.S. 125 (1976); Geduldig v. Aiello, 417 U.S. 484 (1974). The Court recognized in Newport News Shipbuilding and Dry Dock Co. v. EEOC, 462 U.S. $669,670,676$ (1983) that the Pregnancy Discrimination Act, Pub. L. No. 95-555, 92 Stat. 2076 (1979) overruled both General Electric Co. and Geduldig. At other times, courts take realist approaches by invoking laws' underlying purposes. See, e.g., United Steelworkers of Amer. v. AFL-CIO-CLC, 443 U.S. 193, 200-09 (1979) (upholding a race-conscious affirmative action plan against a reversediscrimination claim); $i d$. at 208 (noting that " $[t]$ he purposes of the plan mirror those of the statute [Title V11]").

93. The mechanics of public accommodations laws are discussed in detail infra, at Part III.A.

94. While formal equality emphasizes equal opportunity, substantive equality emphasizes equal outcomes. Under a substantive equality model, the law focuses not only on people's access to public accommodations but also on what people get out of the access. Thus, the realist might argue for guaranteeing substantive access rather than tweaking the existing formal-access approach to public accommodations law. For background on the terms "formal equality" and "substantive equality," see generally Michel Rosenfeld, Substantive Equality and Equal Opportunity: A Jurisprudential Appraisal, 74 CALIF. L. Rev. 1687, 1696-98 (1986).

95. See Note, The Myth of Context in Politics and Law, 110 HARv. L. REv. 1292, 1306 (1997) (arguing "it is unclear that substantive equality is ever fully achievable, to the extent that substantively important factors about identity are beyond the scope of judges' perceptions .... [Substantive equality is] in some sense beyond law's potentiality."). Due to the difficulty of realizing substantive equality through legal decisions, courts often favor formal equality. See Daniel O. Conkle, The Path of American Religious Liberty: From the Original Theology to Formal Neutrality and an Uncertain Future, 75 IND. L.J. 1, 33 (2000) (suggesting that the Supreme Court "has not reduced—and arguably has invigorated-its enforcement of formal equality" because the principle is easy to apply); David S. Schwartz, When is Sex Because of Sex? The Causation Problem in Sexual Harassment Law, 150 U. PA. L. REv. 1697, 1778 (2002) (explaining that judges generally prefer formal equality). 
Sandals to ensure that gay individuals' access to its resorts is meaningful, it would be unclear whether allowing gay individuals to bring their same-sex partners suffices. What if a resort's entertainment catered to the tastes of the average straight couple? Would the resort need to provide entertainment catered to the average gay couple as well? These questions are difficult to answer because it is difficult to discern what is substantively meaningful to individual customers. Looking beyond examples involving gay patrons, consider the difficulty in determining a man's meaningful access to the bra retailer.

To the extent that an individual's "meaningful access" means "access with my chosen partner," formal equality among couples fosters substantive equality among individuals. In that regard, the couples' rights paradigm realizes benefits of both formal and substantive approaches to justice: the couples' rights paradigm furthers substantive equality while preserving the legal clarity of formalism. ${ }^{96}$

The most persuasive argument for protecting couples' rights through the existing individualist framework of antidiscrimination law is the argument that businesses discriminating against a type of couple are essentially discriminating against the individual members of that couple on the basis of their sex. ${ }^{97}$ Framing couples' rights as sex discrimination may appear particularly attractive because sex discrimination is already proscribed by most states' public accommodations statutes. ${ }^{98}$ Indeed, the sexdiscrimination rationale was adopted by a California court in the unpublished-and ultimately withdrawn-opinion of Engel $v$. Worthington, a case in which a commercial photographer refused to photograph same-sex

96. See Conkle, supra note 95 , at 33 (praising formal equality for being a principle that "is conducive to relatively clear-cut exposition and application.").

97. For example, one could argue that the only reason a woman could not have gone to Sandals with another woman is because she is a woman, i.e., because of her scx. For more information on how sexual orientation discrimination is framed as sex discrimination, see ANDREW KoPPELMAN, THE GAY Rights Question in Contemporary American Law 53-7I (2002) [hereinafter Koppleman, The GaY RIGHTS Question]; Andrew Koppelman, Why Discrimination Against Lesbians and Gay Men is Sex Discrimination, 69 N.Y.U. L. REv. 197 (1994) [hereinafter Koppelman, Discrimination]. Framing discrimination against same-sex couples as sex discrimination is, in large part, a product of analogizing same-sex couples to mixed-race couples. See Stephen Clark, Same-Sex but Equal: Reformulating the Miscegenation Analogy, 34 RuTGERS L.J. 107, 107-15 (2002) (providing background on the miscegenation analogy); DeSantis v. Pacific Telephone \& Telegraph Co., 608 F.2d 327, 331 (9th Cir. 1979) (discussing and rejecting appellants argument that because "the EEOC has held that discrimination against an employee because of the race of the employee's friends may constitute discrimination based on race... analogously discrimination because of the sex of the employees' sexual partner should constitute discrimination based on sex.").

98. See Paula J. Finlay, Note, Prying Open the Clubhouse Door: Defining the "Distinctly Private" Club after New York State Club Association v. City of New York, 68 WASH. U. L.Q. 371, 383 (1990) (noting that forty states and the District of Columbia have banned sex discrimination in public accommodations). 
couples. ${ }^{99}$ The court dismissed the plaintiff's sexual orientation argument and reached its decision based on sex discrimination, even though California case law also prohibits public accommodation discrimination on the basis of sexual orientation. ${ }^{100}$

The sex discrimination argument is, however, an unsatisfactory substitute for the couples' rights paradigm, on both practical and normative fronts. From a practical standpoint, the sex discrimination argument is unsatisfactory because its reception by courts has been lukewarm at best. ${ }^{101}$ From a normative standpoint, the sex discrimination argument does not shine due recognition on the couple qua couple. Commentators have expressed their discomfort in shrouding sexual orientation discrimination in terms of sex discrimination. ${ }^{102}$ Although the legal outcome may be functionally equivalent, by not recognizing sexual orientation discrimination as

99. 23 Cal. Rptr. 2d 329 (Ct. App. 1993). The Engel opinion was eventually withdrawn by order of the court. Engel v. Worthington, No. S036051, 1994 Cal. LEXIS 558 (Feb. 3, 1994) (denying review and withdrawing the opinion by order of the court).

100. Sexual orientation is not specifically addressed in the California public accommodations law. Unruh Civil Rights Act. CAL. CIV. CODE ANN. $\S 51$ (West 2005). However, California courts have construed the Act to include sexual orientation as a prohibited basis for discrimination. See Hubert v. Williams, 184 Cal. Rptr. 161 (App. Dep't Super. Ct. 1982) (holding that discrimination based on sexual orientation is a violation of the Unruh Civil Rights Act).

101. The sex discrimination argument has produced mixed results in same-sex marriage cases. For example, in the Vermont case of Baker v. State, 744 A.2d 864, 880-81 n.13 (Vt. 1999), the majority stated, "[W]e are not persuaded that sex discrimination offers a useful analytic framework...." However, in her separate opinion, Justice Johnson adopted the sex discrimination argument. See id. at 904-05 (Johnson, J., concurring in part and dissenting in part) ("I write separately to state my belief that this is a case of straightforward sex discrimination."). In the Massachusetts case of Goodridge v. Dep't of Public Health, Justice Greaney endorsed the sex discrimination argumcnt in his concurring opinion. 798 N.E.2d 941, 971 (Mass. 2003) (Greaney, J., concurring). However, in the same case, three other justices rejected the sex discrimination argument. Id. at 992 (Cordy, J., dissenting, with whom Spina and Sossman, JJ., joined). For other examples of the sex discrimination argument being endorsed in the same-sex marriage context, see Baehr v. Lewin, 852 P.2d 44 (Haw. 1993) (decision rendered moot by amendment to Hawaii's Constitution, art. I, \$23); Coordination Proceeding, Special Title, Marriage Cases, 2005 WL 583129 (Cal. Sup. Mar. 14, 2005). See also Clark, supra note 97, at 109-10 ("Litigants, commentators, and even judges have debated the merits of this sex discrimination argument and its underlying miscegenation analogy as applied to same-sex marriage exclusions, same-sex sodomy laws, and antigay employment discrimination. This sex discrimination argument has sometimes prevailed ... but more often it has failed.").

For a description of the relationship between sex and sexual orientation in Title VII discrimination cases, see Recent Case, Ninth Circuit Holds That Male Coworkers' and Supervisor's Harassment of Male Employee for Failing to Meet Sex Stereotype Constitutes Sex Discrimination, 115 HARV. L. Rev. 2074, 2074-75 (2002) (noting that "[i]t is a common refrain in Title VII jurisprudence that the statutory prohibition on 'discrimina[tion] . . because of ... sex' does not extend to discrimination on the basis of sexual orientation," but noting exceptions involving same-sex sexual harassment)

102. See, e.g., Edward Stein, Evaluating the Sex Discrimination Argument for Lesbian and Gay Rights, 49 UCLA L. REv. 471, 498, 503 (2001); John Gardner, On the Ground of Her Sex(uality), 18 OXford J. LEG. STud. 167, 183 (1998); Danielle Kie Hart, Same-sex Marriage Revisited: Taking a Critical Look at Baehr v. Lewin, 9 Geo. MAson U. Civ. Rrs. L.J. 1, 11 (1998); EsKRidGE, supra note 37 , at 172. 
such, the moral recognition of sexual minorities becomes the marginalized stepchild of sex discrimination principles. ${ }^{103}$

In contrast to the sex discrimination framework, the couples' rights framework recognizes couples by focusing its inquiry on comparing types of relationships. The inquiry emphasizes "same" and "different" in "samesex versus opposite-sex," as opposed to emphasizing "sex." Surely, even in the couples' rights paradigm one needs to ascertain the sex of partners to describe the couples whose rights are at stake, but that sex-based inquiry is not the final question; it is a step in a larger comparison of relationship types. $^{104}$

\section{An Insufficient Alternative to Couples' Rights: Expanding Individual Freedoms of Expression and Intimate Association}

One who is reluctant to depart from the individualist paradigm might attempt to reframe a couple's aggregate right to nondiscrimination as rights to expression and intimate association vested in each member of the couple. But like expanding formal rights of access to substantive rights of access, such reframing raises concerns.

\section{a. Constitutional Claims}

One might argue that a couple's right to access business establishments can be framed as an individual's right to freedom of expression. Under this logic, a federal court in Rhode Island invoked freedom of expression to protect a high school student's right to bring his same-sex date to his public high school's prom. ${ }^{105}$ In that landmark case, the court found that bringing a same-sex partner to the prom constituted political expression. ${ }^{106}$ However, individuals usually cannot make constitutional claims against business establishments because business practices generally lack a nexus with state action. ${ }^{107}$ Business owners currently have the right to

103. 1 do not mean to deny the links between anti-gay sentiments and support for traditional gender roles. See William N. Eskridge, Jr., Multivocal Prejudices and Homo Equality, 74 IND. L.J. 1085, 1110 (1999) (describing those links). However, I believe that remedying sexual orientation discrimination requires putting sexual orientation discrimination front and center.

104. For more on how shifting from the individualist paradigm to the couples' rights paradigm shifts the inquiry from sex to sexual orientation, see infra Conclusion (discussing the shifts in the context of marriage law).

105. Fricke v. Lynch, 491 F. Supp. 381 (D. R.1. 1980).

106. Id.

107. The state action doctrine dictates that the First Amendment only protects against infringement of free expression when the government is responsible for the infringement. See, e.g., Hudgens v. NLRB, 424 U.S. 507, 520-21 (1976) (rejecting a free speech claim against a private shopping mall due to a lack of state action). The Court first announced the state action doctrine in the Civil Rights Cases, 109 U.S. 3 (1883). 
restrict expressive freedoms - of their employees and of their clientelethrough means such as dress codes and bans on foreign languages. ${ }^{108}$

Similarly, one might argue that individuals have existing rights to access couple-oriented businesses with partners of their choosing because the Constitution protects freedom of intimate association. ${ }^{109}$ However, this argument lacks support because freedom of intimate association is generally construed as protecting decisions relating solely to domesticity and, like freedom of expression, the constitutionally protected freedom of intimate association is confined to instances involving state action. ${ }^{110}$

Notably, couples' inability to invoke the Constitution to protect access to business establishments does not directly point to the inadequacy of our Constitution's individual rights framework, but rather to the presently limited reach of those rights as they are interpreted in case law. Unless jurists are ready to radically expand the Constitution's reach, these limitations heighten the need to consider statutory solutions that could reach business establishments. One way to protect couples' access to these businesses, without departing from the individualist paradigm, is to increase legislative protections of free expression and intimate association in commercial contexts that do not involve state action.

\section{b. Statutory Claims}

Statute-based antidiscrimination law currently offers individuals some protection against restrictions on identity expression. However, it generally only protects against group-specific restrictions, such as restrictions on women (but not men) expressing masculinity. ${ }^{11}$ In the employment

108. See, e.g., Garcia v. Gloor, 618 F.2d 264 (5th Cir. 1980) (upholding an office's English-only policy); Rogers v. American Airlines, Inc., 527 F. Supp. 229 (S.D.N.Y. 1981) (upholding an employer's restriction on braided hairstyles).

109. On intimate association, see Roberts v. United States Jaycees, 468 U.S. at 619 (stating that the freedom of intimate association protected by the Constitution extends to a small set of relationships: "those that attend the creation and sustenance of a family-marriage... childbirth ... the raising and education of children ... and cohabitation with one's relatives").

110. See Paul M. Secunda, Lawrence's Quintessential Millian Moment and Its Impact on the Doctrine of Unconstitutional Conditions, 50 VlLL. L. REV. 117, 146 (2005) (asserting that "Lawrence recognize[d] an important limitation on the rights to... intimate association in certain...public circumstances"); Morris B. Kaplan, Constructing Lesbian and Gay Rights and Liberation, 79 VA. L. REv. 1877, 1901 (1993) ("The freedom of intimate association . . emphasizes the creation of intimate spaces.... These intimate spaccs are traditionally and metaphorically represented in terms of the home. Domesticity is the space of intimacy.").

111. See Price Waterhouse v. Hopkins, 490 U.S. 228, 258 (1989) (holding that restrictions on women behaving masculinely violated Title V11); Kimberly A. Yuracko, Trait Discrimination as Sex Discrimination: An Argument Against Neutrality, 83 TEx. L. REv. 167, $177-87$ (2004) (discussing the neutrality principlc in Hopkins and its progeny). There have been some exceptions to the principle of requiring neutrality betwcen groups. See Yuracko, supra at 187 (noting exceptional cases involving malc cross-dressing); Jespersen v. Harrah's Operating Co., lnc., No. 03-15045, 2006 WL 962533, at *5 (9th Cir. Apr. 14, 2006) ("We have long recognized that companies may differentiate between men and women in appearance and grooming policies, and so have other circuits."). In an individualist analysis, 
context, disparate impact claims can be raised, but are rarely successful. Courts will validate restrictions on identity expression, even if such restrictions disparately burden particular individuals, so long as the expression is of a mutable trait. ${ }^{112}$ In public accommodations litigation, disparate impact claims are generally not allowed at all. ${ }^{113}$

In the employment law context, commentators have suggested that statutes be reinterpreted or amended to protect individuals' rights to exercise mutable forms of expression that are integral to those individuals' sense of belonging to protected identity groups. ${ }^{114}$ For example, Paulette Caldwell argues that African-American individuals should have a statutory right to challenge office grooming codes banning braided hairstyles because wearing braids is a type of expression that is potentially integral to one's sense of membership in the African-American community. ${ }^{15}$ Others argue for statutes to prohibit office rules requiring employees to speak English even during breaks because speaking a foreign language is a form of expression that is potentially integral to one's membership in an ethnic minority group. ${ }^{116}$

Although these proposals focus on broadening statute-based proscriptions of discrimination in employment law, their logic can be extended to the context of sexual orientation discrimination in public accommodations. If one's choice in partner is an expression of her sexual orientation, then bringing that partner to a Sandals resort is like wearing braids or speaking a foreign langnage; it is simply the expression of a trait-one that is arguably integral to membership in the lesbian community-and therefore entitled to legal protection. In this fashion, couples' rights to access public accommodations can be framed as individual rights to make expressive traits visible.

restrictions on same-sex coupling are not group-specific because all individuals are equally barred from same-sex coupling, regardless of sex, race, sexual orientation, or any other status.

112. See generally Tristin K. Green, Work Culture and Discrimination, 93 CALIF. L. REv. 623, 656-57 (2005) (providing background on disparate impact claims involving mutable traits and collecting sources).

113. See Harris v. Capital Growth Investors XIV, 805 P.2d 873, 892 (Cal. 1991) (rejecting a disparate impact argument, noting "plaintiffs have cited no case (nor has our research disclosed any) in which a disparate impact test was used in applying any [state or federal public accommodations] statutes.'). But see Robinson v. Power Pizza, Inc., 993 F. Supp. 1462, 1465 (M.D. Fla. 1998) (applying disparate impact theory to a Title II public accommodations case).

114. See Yuracko, supra note 111, at 207-16 (summarizing and critiquing literature that endorses tbe protection of group-identity traits). Kenji Yoshino might go one step further by suggesting that performing an act can be constitutive of group status even if the act lacked expressive functions. Thus, the expanded legal protections should focus on performance as opposed to expressiveness. See Yoshino, supra note 23, at 865-73 (developing Yoshino's "weak performative model" of identity).

I I5. See, e.g., Paulette M. Caldwell, A Hair Piece: Perspectives on the Intersection of Race and Gender, 1991 DUKE L.J. 365, 369 (1991) (suggesting that black women's braids are “[a] positive expression of ethnic pride" warranting statutory protection).

116. See, e.g., Juan F. Perea, Ethnicity and Prejudice: Reevaluating "National Origin" Discrimination Under Title VII, 35 WM. \& MARY L. REV. 805, 808 (1994) (arguing for an expansion of Title VII to protect language rights and other expressions of ethnicity) 
However, the above proposals have been subject to criticism because determining which expressive traits-if any-are integral to one's membership in an identity group is a daunting practice. ${ }^{117}$ The proposals would leave courts assessing questions such as whether braids are really constitutive of membership in the African-American community and whether the Spanish language is really integral to Latino identity. Should courts be left to determine what is integral to group identities and, thus, worthy of protection? The very nature of these inquiries risks judicial essentialization of protected groups. ${ }^{118}$

In contrast, the couples' rights paradigm protects couples while avoiding the similarly essentialist question: which expressive traits are integral to membership in a sexual minority group such as the gay community? The paradigm avoids the essentialist inquiry because the couple is not only an expressive trait of belonging to a larger identity group, but also an identity "group" itself that warrants protection. In the couples' rights paradigm, a ban on a particular type of couple is equivalent to explicit bans on particular racial or religious groups, as opposed to bans on particular racial or religious traits.

In treating couples as collective entities, the couples' rights paradigm addresses situations in which members of same-sex couples do not consider their coupledom a trait expressive of belonging to a larger gay or bisexual community. As noted above, membership in a couple informs one's sense of sexual orientation, even when that individual feels no allegiance to a larger identity group. For example, a woman who is attracted to both men and women might not connect with the group label "bisexual," but may still feel that her current same-sex relationship affirms her sense of sexual orientation. Or, the woman may embrace pomosexuality, ${ }^{119}$ eschewing group categories such as "gay," "lesbian," "straight," and "bisexual." Even if the woman identifies with a relatively obscure label such as "heterosexual-leaning bisexual," she might refuse to characterize her membership in a same-sex couple as an expression of bisexuality. ${ }^{120}$ She

117. For elaboration of this critique, see Yuracko, supra note 111, at 214-16; Roberto J. Gonzalez, Note, Cultural Rights and the Immutability Requirement in Disparate Impact Doctrine, 55 STAN. L. REV. 2195, 2207-14 (2003).

118. Essentialism-the assigning of essential traits to identity groups-overlooks diversity within identity groups and fosters stereotyping. See, e.g., Angela Harris, Race and Essentialism in Feminist Legal Theory, 42 StaN. L. REv. 581, 585-90 (1990) (criticizing racial essentialism and gender essentialism).

119. On pomosexuality, which is short for "postmodern sexuality," see PomoSexuals: Challenging Assumptions about Gender and Sexuality (Carol Queen \& Lawrence Schimel eds., 1997); Mitchel Raphael, Where Gay Goes after the Mainstream, ToRonto STAR, May 17, 1998, at B6 ("In a pomosexual world, sexual categories are no longer rigid. People can move beyond labelsgay, lesbian, bisexual, transsexual ....").

120. Membership in the same-sex couple likely miscommunicates to most people that the hypothetical woman is lesbian and not bisexual. As a descriptive matter, bisexuality often fails to be 
might reject any suggestion that her romantic Sandals getaway is meant to express anything more than a desire for rest and relaxation. The woman and her partner want Sandals to recognize their union, not because it expresses membership in a gay or bisexual community, but because the union is a collective entity that is important im and of itself. Thus, it would be disingenuous to say that the woman has a right to bring her partner to Sandals because the partner is an expressive trait.

Similarly, one may advocate using statutory law to protect individuals' freedom of intimate association in contexts outside of state action. However, even if this freedom is extended beyond the context of state action, it will still under-protect couples. Freedom of intimate association is generally understood as a liberty to make decisions that "attend the creation and sustenance of a family." "121 Classic examples of the freedom of intimate association include the liberty to make decisions regarding cohabitation and child custody. ${ }^{122}$ Accordingly, extending the freedom of intimate association to the commercial context should protect same-sex couples' right to access businesses, such as adoption-relation services, which relate to the creation and sustenance of a family. ${ }^{123}$ However, it would be a stretch to say that any two same-sex dance partners have an intimateassociation interest in the creation and sustenance of a family. Dancing together-or even vacationing together-is not likely to be closely related to the shaping of one's family, while cohabitation and child custody are. However, even when individuals in a couple do not have a liberty claim that qualifies as an intimate association claim, that couple should be permitted to invoke an aggregate right to nondiscrimination. ${ }^{124}$

acknowledged by other sexual minorities and by the heterosexual majority. On this point, see generally Kenji Yoshino, The Epistemic Contract of Bisexual Erasure, 52 STAN. L. REv. 353 (2000).

121. Roberts v. United States Jaycees, 468 U.S. at 619. For concise summaries of the Court's definition of intimate association see Nathaniel Persily, Toward a Functional Defense of Political Party Autonomy, 76 N.Y.U. L. Rev. 750, 818 n.235 (2001); Michael Kavey, Note, Private Voucher Schools and the First Amendment Right to Discriminate, 113 YALE L.J. 743, 758 n.77 (2003). See also Bowers v. Hardwick, 478 U.S. 186, 205 (1986) (Blackmun, J., dissenting) (arguing that sexual intimacy implicates freedom of intimate association because sexual intimacy is, inter alia, "central to family life"). For the article that first articulated a theory of intimate association, see Kenneth L. Karst, The Freedom of Intimate Association, 89 YALE L.J. 624 (1980).

122. See Roberts v. United States Jaycees, 468 U.S. at 619 (listing "the raising and education of children ... and cohabitation with one's relatives" as examples of intimate association right); Karst, supra note 121, at 630-31 (stating "[t]he idea of a freedom of intimate association thus includes a couple's claim of the right to choose to live together . . . but it also ineludes a divorced mother's claim of a right to access to her child who is in the custody of her former husband ...").

123. In a California case, same-sex couples are currently challenging their exclusion from an adoption-related business. See Butler v. Adoption Media, LLC, No. C 04-0135 PJH, 2005 WL 1513142 (N.D. Cal. June 21, 2005) (establishing jurisdiction for the case).

124. Alternatively, an individual might seek to make a hybrid argument based on EEOC decisions that prohibit employers from discriminating against employees based on the race of their friends. Notably however, in the individualist paradigm, the analog hybrid claim is based on sex (not sexual orientation) discrimination, i.e., the claim is that businesses should not discriminate against patrons based on the sex of their partner. Cf. DeSantis v. Pacific Telephone \& Telegraph Co., 608 F.2d 327, 
When businesses exclude couples, that exclusion compromises individuals' liberty interests as well as couples' equality interests. For example, Sandals' exclusion of same-sex couples inflicted a liberty-based wound because it limited people's power to choose their vacation partners and their ability to make expressive traits visible. Sandals also inflicted an equality-based wound by singling out certain couples for deprivation and undercutting their dignity. ${ }^{125}$ Couples should be allowed to articulate both types of wounds. Moreover, couples should be allowed to invoke aggregate rights to remedy the equality-based wound.

III

\section{Towards a Model Public Accommodations Law}

Thus far, I have argued that public accommodations laws should proscribe discrimination against collective entities, as opposed to simply proscribing discrimination against individuals. In this Part, 1 elaborate on that argument by proposing a model public accommodations law and explaining the mechanics related to its enforcement.

As mentioned above, I focus on public accommodations laws because a considerable number of jurisdictions already prohibit public accommodations from discriminating on the basis of "sexual orientation." ${ }^{26}$ However, despite having the potential to protect same-sex couples, public accommodations laws generally have not yet done so. ${ }^{127}$ This Part proposes ways to fulfill that potential.

In Part IlI.A, 1 provide background on public accommodations laws generally and then propose four elements to a model law: (1) a broad definition of "public accommodations," (2) a proscription of sexual orientation discrimination, (3) a specification that distinctions between same-sex and opposite-sex couples constitute per se sexual orientation discrimination, and (4) a provision exempting businesses that satisfy certain criteria discussed below. Although 1 frame this subsection as a legislative proposal, it can also be read as an interpretation and enforcement guide for existing statutes. Some states' public accommodations laws already embody the first, second, and fourth elements of the proposed law. In those states, courts can give life to the third element by adopting a couples' rights approach to interpreting the term "sexual orientation" in their existing laws.

331 (9th Cir. 1979) (discussing and rejecting appellants' argument that because "the EEOC has held that discrimination against an employee because of the race of the employee's friends may constitute discrimination based on race... analogously discrimination because of the sex of the employees' sexual partner should constitute discrimination based on sex"). See also Karst, supra note 121, at 65964 (suggesting that intimate association claims can be anchored in equal protection doctrine).

125. On the dignitary harms of exclusion, see supra notes 86-87 and accompanying text.

126. See supra note 29.

127. For a discussion of the limited and inconsistent litigation under existing public accommodation laws, see supra note 88 and accompanying text. 
In Part III.B, I elaborate on some of the key terms that are relevant to the proposed law.

\section{A. Integrating Couples' Rights and Public Accommodations Law}

\section{Background on Public Accommodations Laws}

There are currently two federal public accommodations laws: Title II of the 1964 Civil Rights Act $^{128}$ and Title III of the Americans with Disabilities Act. ${ }^{129}$ At the same time, most states and local jurisdictions have their own public accommodations laws. These regulations generally create a right of equal access to public accommodations. ${ }^{130}$ The most expansive laws include business establishments within the definition of "public accommodations." 131

Public accommodations laws regulating businesses require such establishments to refrain from discriminating against potential patrons on specified bases such as race, sex, disability status, and sexual orientation. Although public accommodations laws usually only require businesses to passively refrain from discriminatory conduct, they sometimes require businesses to actively remedy institutionalized discriminatory practices. For example, a railroad company could be ordered to remove signs prohibiting racial minorities from accessing certain cars. Similarly, a shopping mall might be enjoined to create wheelchair ramps for remedying unequal access between patrons ni wheelchairs and patrons on foot.

Because public accommodations laws generally stop at access, ${ }^{132}$ business establishments have no duty to alter their products or services to

128. 42 U.S.C. $\S 2000 \mathrm{a}(2000)$.

129. 42 U.S.C. $\$ 12182$ (a) (2000) [hereinafter ADA].

130. See Lauren J. Rosenblum, Note, Equal Access or Free Speech: The Constitutionality of Public Accommodation Laws, 72 N.Y.U. L. Rev. 1243, 1243 (1997) (explaining that "[ $t$ ]he public accommodations statutes of most states and many municipalities ... were enacted to ensure that all members of society have equal access to goods and services") (emphasis added).

The public accommodations provision in the 1964 Civil Rights Act uses the term "equal enjoyment" as well as "equal access." 42 U.S.C. $\S 2000$ a (2000) ("Equal Access. All persons shall be entitled to the full and equal enjoyment of the goods, services, facilities, privileges, advantages, and accommodations of any place of public accommodation...."). However, the Supreme Court has conflated the terms, essentially defining enjoyment as access. See Daniel J. Trainor, Comment, Native American Mascots, Schools, and the Title VI Hostile Environment Analysis, 1995 U. ILL. L. REV. 971, 998 ("The Supreme Court has interprcted 'enjoyment' in [Title II of the Civil Rights Act of 1964] to mean access, not personal fulfillment or joy."). See also Heart of Atlanta Motel, 379 U.S. at 250 (1964) (noting that the "fundamental object of Title VIl was to vindicate the deprivation of personal dignity that surely accompanies denials of equal access to public establishments"') (emphasis added) (internal citations omitted), and quoted in Roberts $v$. United States Jaycees, 468 U.S. at 625.

A notable outlier is the ADA, Pub. L. No. 101-336, 104 Stat. $327,(1990)$, codified at 42 U.S.C. $\S$ 12182(a) (2000). Courts have found that the ADA's public accommodations provision protects more than access. This exception will be discussed infra, at notes 182-187 and accompanying text.

131. See discussion infra, at notes 141-142 and accompanying text.

132. See supra note 130 (noting the ADA as an exception); see also infra, at notes 182-187 and accompanying text. 
ensure that patrons derive equal utility from accessed goods and services. ${ }^{133}$ A retailer can sell women's clothing while maintaining no obligation to sell men's clothes. That retailer, however, may not restrict men from entering the store and purchasing women's clothing, even if men generally find little utility in women's clothing. Indeed, businesses may specialize their products but may not restrict access to products just because they are specialized. The question of whether to purchase a specialized product is a decision left to the consumer. Choosing not to purchase a useless product is, to some degree, an act of empowerment. The customer is exercising her freedom of autonomous decision-making. Meanwhile, being excluded from that decision-making process can be debilitating. The excluded party is left to question why she was excluded. Was she adjudged to be inferior? Misrecognized? Unrecognized?

Various examples illustrate this dynamic between specialized products and customer choice. For instance, a law office can specialize in representing women in divorce cases. However, the law office, as a public accommodation, cannot discriminate against potential male clients. ${ }^{134}$ It must ultimately be the customer who decides whether the product is right for him. Similarly, a bar may market its "Ladies' Night," but may neither entirely prohibit men from attending, ${ }^{135}$ nor charge lower prices of admission for women, rendering men's access to the bar unequal. ${ }^{136} \mathrm{~A}$ beautician can market himself as a specialist in braiding African-American hair, but may not hang a "Blacks Only" sign in his window.

133. See, e.g., Stearnes v. Baur's Opera House, lnc., 788 F. Supp. 375, 378 (C.D. Ill. 1992) (holding that a dance club did not violate the public accommodations provision of the 1964 Civil Rights Act when it refused to play music that black patrons enjoyed), rev' $d$ on jurisdictional grounds, 3 F.3d 1142 (7th Cir. 1993); Phillips v. Interstate Hotels Corp., 974 S.W.2d 680 (Tenn. 1998) (stating that a hotel did not violate Tennessee's public accommodations laws by playing music that deterred black patronage). See also supra note 130 (noting the conflation of "access" and "enjoyment" in jurisprudence on the public accommodations provision).

134. See, e.g., Stropinsky v. Nathanson, 19 M.D.L.R. 39 (M.C.A.D. 1997) (finding that a law firm specializing in representing women in divorce cases violated Massachusetts's antidiscrimination law by refusing to represent a man).

135. See, e.g., Easebe Enters., Inc. v. Alcoholic Beverage Control Appeals Bd., 190 Cal. Rptr. 678 (Ct. App. 1983) (revoking a liquor license from Chippendales, a cabaret bar featuring scmi-nude male dancers, because it violated California's public accommodations law by refusing to permit male customers from entering its premises during the dance performances).

136. Out of the nine states that have addressed sex-based discounts, six held that the discounts were per se violations of public accommodations laws. See Gillespie v. J.C.B.C., 1nc., No. CRT 2579 03, 2004 WL 1476932, at *1 (N.J. Office Admin. L. June 10, 2004); Ladd v. lowa West Racing Ass'n, 438 N.W.2d 600 (lowa 1989); City of Clearwater v. Studebaker's Dance Club, 516 So. 2d 1106 (Fla. Dist. Ct. App. 1987); Peppin v. Woodside Delicatessen, 506 A.2d 263 (Md. Ct. Spec. App. 1986); Koire v. Metro Car Wash, 707 P.2d 195 (Cal. 1985); Penn. Liquor Control Bd. v. Dobrinoff, 471 A.2d 941 (Pa. Commw. Ct. 1984). The three remaining states held that sex-based discounts do not violate public accommodations laws when their purpose is to increase overall patronage. See Dock Club, lnc. v. 111. Liquor Control Comm'n, 428 N.E.2d 735 (111. App. Ct. 1981); MacLean v. First Northwest lndus. of Am. 635 P.2d 683 (Wash. 1981); Tucich v. Dearborn Indoor Racquet Club, 309 N.W.2d 615 (Mich. Ct. App. 1981). 
With all of that said, the right of access created by public accommodations laws is not absolute. Although public accommodations regulations vary from jurisdiction to jurisdiction, they generally excuse business establishments under a limited set of circumstances, which have been referred to as circumstances involving a bona fide business interest. ${ }^{137}$ Courts have narrowly construed these exceptions. Catering to customer preferences to avoid losing business is not itself a bona fide business interest. ${ }^{138}$ However, customer preference does create a bona fide business interest when it is rooted in liberty interests such as privacy, health, or safety. For example, restrooms and locker rooms have generally been exempt from public accommodations laws. ${ }^{139}$ The purported reasoning is that sex segregation in these contexts protects a privacy interest and thus is part of a legitimate business interest. ${ }^{140}$ Although privacy is the liberty interest most often invoked to exempt businesses from public accommodations laws, some states have also created exceptions for businesses that discriminate when that discrimination protects patrons' health or safety. ${ }^{141}$ Additional

137. See Eugene Volokh, The California Civil Rights Initiative: An Interpretive Guide, 44 UCLA L. REV. 1335, 1365-66 (1997) (noting ubiquity of the "bona fide qualification" in state public accommodations laws).

138. See Heart of Atlanta Motel, 379 U.S. at 260 (stating that potential economic loss suffered by public accommodations did not render the Civil Rights Act of 1964 unconstitutional); LivingWell (North) Inc. v. Penn. Human Relations Comm'n, 606 A.2d 1287, 1289 (Pa. Commnw. Ct. 1992) (asserting that an exemption is "not normally warranted in a situation involving customer preference"). Consider the analogous situation in employment discrimination cases, e.g., Diaz v. Pan Am. World Airways, Inc., 442 F.2d 385, 389 (5th Cir. 1971) (holding that consumer preferences did not justify the maintenance of an all-female flight attendant staff).

139. See, e.g., LivingWell, 606 A.2d at 1289, 1291 :

[An exemption is] not normally warranted in a situation involving customer preference unless associated with recognized privacy rights.... [W] here there is a distinctly private activity involving exposure of intimate body parts, there exists an implied bona fide public accommodation qualification which may justify otherwise illegal sex discrimination. Otherwise, as the Commission notes, such sex segregated accommodations such as bathrooms, showers and locker rooms, would have to be open to the public.

See also Volokh, supra note 137, at $1365 \mathrm{n} .95$ (listing examples of privacy-based exemptions in different states). In some jurisdictions the privacy rationale has been extended to exempt single-sex fitness clubs from public accommodations laws. See MASs. GEN. LAws ANN. ch. 272, § 92A (West 2000) (exempting fitness clubs in Massachusetts); Miriam A. Cherry, Exercising the Right to Public Accommodations: The Debate over Single-Sex Health Clubs, 52 ME. L. REv. 97, 99 (2000) (describing the history of the Massachusetts law; noting that it was supported by privacy-based arguments). See also LivingWell, 606 A.2d at 1294 (accepting the privacy argument asserted by an all-female fitness club in Pennsylvania and refusing to order the club to admit men because "no reasonable alternative exists to protect LivingWell's customer's privacy interests while at the same time accommodating male members").

140. See supra note 139.

141. On health-based exceptions, see Karen H. Rothenberg, Gender Matters: Implications for Clinical Research and Women's Health Care. 32 Hous. L. Rev. 1201, 1256-58 (1996) (discussing a narrowly defined exception in some public accommodations laws that allows medical service providers to distinguish between sexes). On safety, see, e.g., Lewis v. Doll, 765 P.2d 1341, 1342 (Wash. Ct. App. 1989). The court noted that Washington law permits public accommodations to discriminate among patrons when doing so prevents "risk to property or other persons." See id. (quoting WASH. REV. CODE $\S 49.60 .215(2002)$ ). 
exceptions exist in the context of disabilities law; however, this Essay later distinguishes the disabilities context from the rest of public accommodations jurisprudence. ${ }^{142}$

Notably, privacy-based exemptions should not carry over to the sexual orientation context. Indeed, an impetus for this Essay is to bring same-sex relationships into the public sphere; allowing businesses to discriminate against sexual orientation through a privacy exemption would undermine that process. Overt sexual activity between members of couples (regardless of their sexual orientation) might be deemed inappropriate for the public sphere; however, such conduct is already regulated by laws prohibiting public nudity and lewdness. As a general matter, barring access to public accommodations based on sexual orientation is unnecessary to preserve the private nature of sexual activity. ${ }^{143}$

\section{Public accommodations and sexual orientation: a proposed framework}

To protect against sexual orientation discrimination, this Essay proposes four elements for a model public accommodations statute:

1) The law should broadly define "public accommodations" to include all business establishments, including sellers of retail goods and services.

2) The law should protect equal access to public accommodations by prohibiting discrimination on the basis of "sexual orientation."

3) Distinctions between opposite-sex and same-sex couples should constitute per se discrimination on the basis of sexual orientation. ${ }^{144}$

4) The law should create a narrowly defined exception for businesses that invoke a bona fide business interest. ${ }^{145}$

142. The ADA qualifies its public accommodations provision by exempting cases in which compliance would expose the public accommodation to "undue burden" or would otherwise "fundamentally altcr" the public accommodation. See 42 U.S.C. $\S 12182$ (2000). These excmptions require fact-intensive, case-by-case assessments. Compare Martin v. PGA Tour, lnc., 994 F. Supp 1242 (D. Or. 1998) (finding that permitting a disabled professional golfer to use a golf cart instead of walking during a tournament did not fundamentally alter the nature of the tournament), affd $204 \mathrm{~F} .3 \mathrm{~d}$ 994 (9th Cir. 2000) and 532 U.S. 661 (2001), with Elitt v. U.S.A. Hockey, 922 F. Supp. 217 (E.D. Mo. 1996) (finding that permitting a family member on the ice to direct moves for a player with Attention Deficit Disorder would fundamentally alter the hockey league's game). Though the ADA's underlying principles offer guidance in proposing a model public accommodations law for the sexual orientation context, the Act must ultimately be distinguished as being inapposite because courts have construed it as protecting more than just access. See infra notes 182-187 and accompanying text.

143. One exception is when the nature of a business establishment requires couples to interact on a physical level, for example, in cases involving square dancing. These exceptional cases will be discussed infra, at Part 11I.B.2.

144. For a discussion on why the proposed law focuses on discrimination between types of couples as opposed to discrimination between couples and polyamorous unions, see supra note 64 .

145. This exccption will be explored in greatcr detail infra, at Part 111.B.2. 
The first, second, and fourth elements are not entirely novel. With respect to the first element, some state public accommodations laws already broadly construe "public accommodations" to include all business establishments. For example, California's public accommodations statute expressly states that "all business establishments" are considered public accommodations. ${ }^{146}$ Likewise, New Jersey's law extends to any "retail shop, storc, establishment, or concession dealing with goods or services of any kind." 147

Laws did not always broadly construe public accommodations. Historically, common law public accommodations rights were travelers' rights. ${ }^{148}$ Old English law required establishments such as inns and saloons to accommodate potential guests in order to ensure that travelers had basic living needs met. ${ }^{149}$ In the post-Civil War era, however, public accommodations laws took on a new meaning. Civil rights advocates saw a relationship between discrimination in public accommodations and cultural citizenship ${ }^{150}$ and subscription to this conceptualization of public accommodations law grew during the mid-twentieth century's civil rights movement. ${ }^{151}$ Over time, denying access to a public accommodation has come to be viewed as a form of oppression. In response, many jurisdictions are defining "public accommodations" more broadly to further principles of equality. This Essay advocates a broad definition of public accommodations because only such a definition will adequately achieve the goal discussed in Part I-protecting sexual minorities' recognition rights in the public sphere. ${ }^{152}$

The second element is also not novel. Fifteen states already have public accommodations laws that proscribe discrimination on the basis of sexual orientation, ${ }^{153}$ and that number will likely rise. As of December 2005, seven additional state legislatures are considering antidiscrimination bills

146. Cal. Civ. Code § 51(b) (West 2005).

147. N.J. Stat. ANN. \& 10:5-5 (West 2002).

148. For a history of public accommodations regulations at common law, see Joseph William Singer, No Right to Exclude: Public Accommodations and Private Property, 90 Nw. U. L. Rev. 1283, 1303-20 (1996).

149. See id. at 1304-05.

150. On cultural citizenship, see supra note 34.

151. See Hunter, supra note 34 , at 1617-24.

152. One should note that most public accommodations laws maintain an exception to the definition of "public accommodations" for private clubs. See generally Jay M. Zitter, What Constitutes Private Club or Association Not Otherwise Open to Public that is Exempt from State Civil Rights Statute, 83 A.L.R.5th 467 (2004). This Essay does not propose abrogating that exception. However, even private clubs can be deemed public accommodations if their membership and activities are substantially public in nature. $I d$.

153. See supra note 29. 
that will protect against sexual orientation discrimination in public accommodations. ${ }^{154}$

As discussed above, the fourth element is well established in public accommodations law. Lawmakers have traditionally limited the reach of public accommodations laws by creating exceptions for bona fide business interests. Part III.B explores in more detail how such exceptions should be defined in the context of sexual orientation discrimination.

The primary innovation in the proposed model is the third element. As discussed in Part II, for serious treatment of sexual orientation rights, rights must be attributed both to the individual and the collective entity. Because one's coupling preference is fundamentaI to one's sexual orientation, the couple and the individual cannot be disaggregated. For a business to tell a lesbian that she can purchase a couple-oriented product—such as a Sandals hotel room - but can only use the product with a man is akin to asking her to check her sexual orientation at the door. That request is analogous to telling a woman that she can purchase a product, but only if she leaves her genitalia behind when she enters a store ${ }^{155}$ and is also analogous to requiring black men to shed their skin to access a particular business establishment. These types of disaggregation are unacceptable, and so too is the disaggregation of the lesbian individual and her coupling preference.

\section{B. Defining Compliance with the Proposed Law}

The model's first element defines "public accommodations" to broadly cover all business establishments, including resorts like Sandals, the hypothetical ballroom dance studio, and eHarmony. ${ }^{156}$ Thus, these establishments need to accommodate both opposite-sex and same-sex couples. ${ }^{157}$ The remainder of Part III.B discusses what it means for businesses to accommodate same-sex and opposite-sex couples under the model regulation. Specifically, Part III.B addresses how to define access with regard to couples, and how to define the limits of the law's reach.

154. Those states are Delaware, lowa, Kansas, Michigan, Nebraska, Ohio, and West Virginia. Human Rights Campaign, Equality: from State to State 2005 43-50 (2005). In addition, Hawaii has pending legislation to expand its proscription of sexual orientation discrimination in public accommodations. $I d$. at 45 . Hawaii already prohibits sexual orientation discrimination in public accommodations that receive state financial assistance. HAw. REV. STAT. ANN. § 368-1 (2004).

155. Although 1 do not endorse defining womanhood by physiology alone, courts have suggested that certain physiological characteristics are essential to the female sex. See, e.g., Michael M. v. Superior Court, 450 U.S. 464, 467 (1981) (justifying a sex-based classification by noting the "'immutable physiological fact that it is the female exclusively who can become pregnant") (quoting Michael M. v. Superior Court, 601 P.2d 572, 574 (Cal. 1979)).

156. For purposes of this Essay, I assume that the proposed law would be enacted in such a fashion that these businesses would satisfy any jurisdictional requirements related to the law's enforcement.

157. This requirement would bc subject to a reasonableness limitation. See infra Part III.B.2. 


\section{Defining Access with Regard to Couples}

As noted above, coupling preferences are inextricably linked to sexual orientation, and businesses distinguishing between opposite-sex and samesex couples discriminate per se based on sexual orientation. Thus, to satisfy the proposed model's protection of equal access to public accommodations, businesses must not limit access by distinguishing between opposite-sex and same-sex couples. Furthermore, as dictated by the moral theories developed earlier in this Essay, entities considered "couples" include potential couples as well as long- and short-term couples. ${ }^{158}$ As a result under the proposed law, businesses like Sandals are not permitted to bar lesbian couples from honeymooning at their couples-oriented resort. At the ballroom dance studio, two men wishing to dance in a same-sex pairing must be allowed to do so, even if they are not a long-term romantic couple. Finally, eHarmony is not permitted to match only opposite-sex couples.

Of course, requiring these businesses to accommodate same-sex couples simply means they need to provide same-sex couples with access. Niche marketing itself is not illegal. They may continue specializing their products and services by catering to opposite-sex couples. For example, an mstructor at the dance studio may choreograph his dances with oppositesex couples in mind. He might formulate a partnered dance where one partner's gestures convey masculinity while the other's gestures adopt a feminine role. However, the instructor cannot prevent two women from defying gender stereotypes by paying the studio to learn the instructor's dance. ${ }^{159}$ Similarly, a dating service may specialize in matching either opposite-sex or same-sex couples; however, it may not explicitly refuse access $^{160}$ to individuals who view themselves as belonging to the non-targeted type of "potential" couple. This right of access for sexual minorities parallels the inclusion required of businesses targeting a niche market based on race. In jurisdictions with capacious definitions of "public accommodations," a dating service may specialize in matching

158. See supra, Part II.C.

159. Requiring businesses to disaggregate their notions of sex and gender is nothing new. For example, businesses often advertise their products as "women's products." These businesses range from Chippendales to "women's" shoe stores to a shop like Jessica McClintock, which specializes in frilly dresses. Despite the feminine nature of these establishments, Chippendales may not bar men from viewing its shows; the shoe store cannot stop a man from trying on a pair of stiletto heels; and Jessica McClintock cannot stop a man from holding a dress up against himself while peering into a store mirror. For an example of relevant case Iaw, see Easebe Enterprises, Inc. v. Rice, I90 CaI. Rptr. 678 (Ct. App. 1983) (revoking a liquor license from Chippendales, a cabaret bar offering striptease performances geared towards female audiences, because it violated California's public accommodations law by prohibiting male customers from entering its premises during the dance performances).

I60. In the case of online dating serviees, 1 define "access to service" as the ability to purchase matching services, not the ability to Iog on to the website. Reasoning by analogy, I see being able to log on but unable to purchase services as similar to being permitted to walk into a restaurant but being refused a table and menu. 
Asian-American couples and may advertise this specialization, but may not refuse access to patrons of other races. ${ }^{161}$

Online dating services like Match.com, Lavalife, Salon Personals, and Gay.com already satisfy the proposed law. ${ }^{162}$ The first three services ask patrons to complete a profile that specifies their sex as well as the sex of their desired partner. On Match.com, patrons may fill in the first blank with either "Man" or "Woman," and the second blank with "Men" or "Women." Similarly, on Lavalife, the options for both blanks are "Male" and "Female." On Salon Personals, patrons have more options; they must specify whether they are a "man," "woman," "couple $(\mathrm{m} / \mathrm{f})$," "couple $(\mathrm{m} / \mathrm{m})$," or "couple $(f / f)$," and whether they are looking for a "man," "woman," "man or woman," "couple $(\mathrm{m} / \mathrm{f})$," "couple $(\mathrm{m} / \mathrm{m})$," or "couple $(\mathrm{f} / \mathrm{f})$." By framing their profile surveys in such fashion, these dating services match both same-sex and opposite-sex couples. In the case of Salon Personals, the service also facilitates polyamorous unions. ${ }^{163}$

Gay.com also provides access to all types of potential couples. The service simply prompts patrons with the question: "Find __." Patrons may select from "Men," "Women," "MTF," "FTM,"164 and "All." Gay.com also asks its patrons whether they consider their sexuality to be "gay," "lesbian," "bisexual," "straight," "queer," or "questioning." One's answer to the sexuality question does not limit the options from which one may choose to complete the "Find __ query. Gay.com is a business that

161. Although there are no reported cases in which people have sued dating services for serving only a particular race, I assume that refusing access to these services based on race is illegal because exemptions to public accommodations laws are so narrowly defined. See supra notes 132-137 and accompanying text (diseussing exceptions to public accommodations laws). Also, consider Click2Asia.com, http://www.click2asia.com (last visited Apr. 21, 2005), an online dating service that specializes in matching Asian Americans but does not bar non-Asian Americans from accessing its services, and JDate, http://www.jdate.com (last visited Apr. 21, 2005), an online dating service that specializes in matching Jewish couples but does not bar non-Jews from accessing its services. It may seem ironic to subject dating services to antidiscrimination laws since dating inherently involves discrimination. For example, if a woman decides to date only white men, she is discriminating against women and racial minorities. However, an individual who discriminates among potential partners can be distinguished from a dating service that discriminates against potential customers. In the former situation, antidiscrimination principles are outweighed by the individual's freedom to choose her intimate associations; in the latter situation, there is no intimacy interest hetween the business and its potential customers. See Roberts v. United States Jaycees, 468 U.S. at 631-34 (O'Connor, J., concurring) ("[C]ertain personal relationships or decisions are protected from govemment interference.... [However, the] Constitution does not guarantee a right to choose employees, customers, suppliers, or those with whom one engages in simple commercial transactions, without restraint from the State.").

162. See, e.g., Match.com, http://www.match.com; (last visited Apr. 21, 2005); Lavalife.com, http://www.lavalife.com (last visited Apr. 21, 2005); Salon Personals, http://personals.salon.com (last visited Apr. 21, 2005); Gay.com, http://www.gay.com (last visited Apr. 21, 2005).

163. For an explanation on why this Essay's proposed law does not address polyamory, see supra note 64 .

164. The categories "MTF" and "FTM" account for transgendered persons. MTF stands for "male to female," while FTM stands for "female to male." 
heavily markets itself to the gay community, but the service accommodates diverse sexual orientations by providing access to same-sex couples, opposite-sex couples, and couples that include transgendered persons.

In contrast to the aforementioned services, eHarmony refuses to match same-sex couples. ${ }^{165}$ Its customer profile survey requires patrons to identify their own sex; afterwards, eHarmony presumes that each patron is seeking a partner of the opposite sex. This presumption results in providing access only to opposite-sex potential couples. Under the proposed law, eHarmony would be required to modify its website and its compatibility survey to provide selection options for same-sex couples, that is, unless it could invoke one of the bona fide business interests described in Part III.B.2.

One might ask why public accommodations laws should regulate businesses like eHarmony when other services such as Gay.com already match same-sex couples. The answer lies in recognizing that Gay.com's inclusion cannot remedy the stigmatization produced by eHarmony's exclusion. Consider an analogous case based on race: the mere existence of a restaurant that welcomes black patrons cannot remedy the wound inflicted by a restaurant down the road with a sign saying "No Blacks." Even if race and sexual orientation discrimination are not equivalents, exclusion in both contexts inflicts a significant wound. ${ }^{166}$ Indeed, commentators have already criticized eHarmony's policy as unjust. ${ }^{167}$

\section{Bona Fide Business Interests as a Limiting Principle}

The right of access created by public accommodations laws has never been absolute. ${ }^{168}$ Across various jurisdictions, policymakers and courts have exempted businesses that justify discrimination with a bona fide business interest. This Essay proposes preserving that tradition by including a "bona fide business interest" exception in the proposed law. To clarify the exception, I discuss three types of business interests and evaluate their merits. Part III.B.2.a asserts that businesses do have a bona fide business interest in protecting patrons against compelled bisexuality. Forcing bisexuality upon patrons jeopardizes patrons' liberty interests in developing their own notions of sexual identity. Similarly, Part III.B.2.b contends that businesses $d o$ have a bona fide business interest in discriminating when compliance with the proposed law creates an undue burden. However, Part III.B.2.c

165. See supra note 1 .

166. On the wounds associated with exclusion, see supra notes 87-89 and accompanying text. On why it is appropriate to sometimes analogize between race and sexual orientation discrimination, see Sharon Elizabeth Rush, Equal Protection Analogies-Identity and "Passing": Race and Sexual Orientation, 13 HARV. BLACKLETTER L.J. 65 (1997); Margaret M. Russell, Lesbian, Gay and Bisexual Rights and "The Civil Rights Agenda," I Afr.-AM. L. \& PoL'y ReP. 33 (1994).

167. See supra, notes 1-2.

168. See discussion supra at notcs $137-43$ and accompanying text. 
argues that businesses do not have a justification for discrimination simply because compliance with the proposed law requires product modification.

\section{a. Preventing Compelled Bisexuality}

Couple-oriented businesses have a legitimate interest in avoiding compelling, or inadvertently privileging, bisexuality when providing equal access to diverse couples. In some contexts-such as square dancing associations and dating services-businesses might find that removing distinctions between types of couples creates a bisexual norm. In the exceptional cases where privileging bisexuality is a concern, businesses should be permitted to satisfy the proposed law by offering separate-but-equal access to different types of couples. This is because replacing the traditional heterosexual norm with a bisexual norm merely replaces one form of discrimination with another.

One type of exceptional case privileging bisexuality involves the commingling of couples. By using the term "commingling," I am referring to circumstances where couples actually swap partners, blurring the lines between sets of couples. For illustration purposes, substitute the hypothetical ballroom dance studio with a square dance association that qualifies as a public accommodation. ${ }^{169}$ In the case of square dancing, individuals do not only dance with primary partners; dance steps often require switching partners. If a same-sex couple and an opposite-sex couple participate in the same square dance, they may end up switching partners with each other. In effect, all dancers at an integrated square dance face the possibility of dancing with partners of both the same and opposite sex. Therefore, in the case of square dancing, the commingling of couples enforces a bisexual norm. One possible solution for the square dance establishment is to offer one night of the week to satisfy lesbian patrons and another night of the week for gay men. However, the duty to offer separate-but-equal access is only required insofar as such offerings do not create an undue burden. ${ }^{170}$

One might argue that the commingling of couples is no more objectionable than the commingling of races. For example, an Asian-American couple may wince at the thought of swapping partners with a Latino couple. Should that visceral wince justify segregating Asian-American dance partners from Latino partners? The difference between race and sexual orientation is that racial identity is not inextricably linked with one's relational status in a couple whereas one's sexual orientation necessarily

169. Based on their activities and membership criteria, some private associations may not qualify as public accommodations. See supra note 152 and accompanying text.

170. As I discuss in the subsection on undue burdens, infra Part 111.B.2.b, "equal" in "separate but equal" is tempered by feasibility concerns. Thus, the square dance association should only need to offer two nights of same-sex dancing if its financial situation renders more nights unfeasible. 
depends on relational desire. ${ }^{171}$ Thus, requiring the commingling of opposite-sex and same-sex couples is particularly objectionable. Separate-butequal access is deemed satisfactory only under such circumstances.

A second type of exceptional case privileging bisexuality involves establishments in the business of matching couples. Consider a business like HurryDate, which matches couples online as well as offline through "speed dating"172 parties. Under the proposed law, HurryDate is required to match both opposite-sex and same-sex couples. But if HurryDate does not segregate its clientele based on sexual orientation, gay patrons could potentially be matched with straight patrons, creating another sort of compelled bisexuality. To avoid privileging bisexuality, HurryDate can offer separatebut-equal speed dating arrangements, as long as doing so does not create an undue burden. For example, HurryDate could partition a set of tables at the speed dating party for gay couples and another set of tables for lesbian couples. Alternatively, HurryDate could organize separate speed dating events on separate evenings ${ }^{173}$

Preventing the privileging of bisexuality is a legitimate justification for discrimination because privileging bisexuality implicates a liberty interest-namely one's right to develop her own sexual identity, which is the liberty interest at the heart of this Essay. By compelling bisexuality, the law suppresses the sexual orientation of gays, lesbians, and straights alike. Liberty interests such as patrons' privacy, safety, and health have served as bona fide business interests in the past. ${ }^{174}$ This Essay simply extends that rationale to the context of couple-oriented discrimination.

\section{b. Avoiding Undue Burdens}

Requiring businesses to comply with the proposed law may create excessive financial burdens for those affected. The ADA excuses businesses from complying with its public accommodations provision if they

171. I acknowledge that the race of one's partner can affect one's racial identity. Eric Liu illustrated this fact in THE ACCIDENTAL AsIan 33 (1998), when he wrote, "[h]ere are some ways you could say 1 am 'white', . 1 married a white woman." Nonetheless, race and sexual orientation are distinguishable. While racial identity is possibly affected by relationships, sexual orientation is necessarily dependent on a relational measure. Liu listed twenty-four reasons why he felt white despite his yellow skin. Id. at 33-34. In contrast, a homosexual woman has only one reason why she is homosexual: she directs her sexual interest towards other women. On the relational nature of sexual orientation, see supra notes 62-71 and accompanying text. Note that, in this footnote, 1 use the term "homosexual" as opposed to "lesbian." The two terms overlap, but not perfectly. While there is only one reason why a woman is homosexual, there can be multiple reasons why women identify as lesbian. That category has become not only a sexual orientation, but also a cultural and political identity. See, supra note 8 (discussing lesbianism as both a sexual orientation and a political identity).

172. At speed dating parties, HurryDate appoints its patrons to a series of three-minute blind dates. See Hurrydate.com, http://www.hurrydate.com (last visited Apr. 21, 2005)

173. Notably, HurryDate already satisfies the proposed law because it presently offers its services to both same-sex and opposite-sex couples. Id.

174. See supra notes 137-143 and accompanying text. 
prove that doing so imposes an undue burden, which consists of a financial loss and the establishment's inability to absorb that loss. ${ }^{175}$ Like the ADA, the proposed law will expose some couple-oriented businesses to significant financial burdens. As a result, this Essay proposes creating a bona fide qualification for businesses that can prove an undue burden. The financial burdens analysis is necessarily a fact-based assessment in which courts determine where to draw the line between due and undue burdens-a line that is essentially a question of reasonableness. With that said, there are three principles that should guide courts' analyses.

First, the costs incurred by acting against a customer preference for discrimination should never be deemed an unreasonable financial burden. ${ }^{176}$ Doing so contravenes the express purpose of the law: to counter discrimination. For example, the ballroom dance studio might argue that providing access to same-sex couples burdens the studio with economic loss because the studio's existing opposite-sex couples do not wish to dance among same-sex couples. As a result, patronage from opposite-sex couples will decrease. Under the model regulation, a business's interest in preserving its marketability as an exclusively opposite-sex establishment does not exempt it from the law. Customer preferences do not excuse businesses' discriminatory practices. The dance studio cannot hang a "No Blacks" sign on its door just because some of its patrons wince at the idea of dancing among black couples. ${ }^{177}$ That reasoning translates to the context of couples and sexual orientation.

Second, financial loss alone should never constitute an undue burden. ${ }^{178}$ To assess the weight of the burden, courts should weigh the financial loss against the business's resources. ${ }^{179}$ Larger businesses are usually

175. In interpreting the ADA, the Department of Justice defines "undue burden" as a "significant difficulty or expense." See 28 C.F.R. $§ 36.104$. (2005). Factors to consider include the cost of the action needed to comply with the ADA's public accommodations provision and the overall financial resources of the public accommodation involved. See id.

176. Customer preference generally does not create a legitimate business interest. For a discussion on customer preference and its relation with economic loss, see supra note 138 and accompanying text.

177. Cf. Palmore v. Sidoti, 466 U.S. 429, 433 (1984) (discussing whether catering to private biases can ever justify race-based govemment discrimination and noting that the govemment must not "bow[] to the hypothetical effects of private racial prejudice that they assume to be both widely and deeply held") (quoting Palmer v. Thompson, 403 U.S. 217, 260-61 (1971) (White, J., dissenting)). In City of Dallas v. Stanglin, 490 U.S. 19, 25 (1989), the Supreme Court stated, "we do not think the Constitution recognizes a generalized right of 'social association' that includes chance encounters in dance halls." That lack of a constitutional right to social association suggests that there is also no right to social disassociation that would protect one's desire not to dance among certain groups.

178. See Heart of Atlanta Motel, 379 U.S. at 260 (stating that potential economic loss suffered by public accommodations did not render the Civil Rights Act of 1964 unconstitutional).

179. This factor-balancing approach to assessing burdens is adopted from the ADA context. See 28 C.F.R. $\$ 36.104$ (2005) (listing factors to balance, which include the nature and cost of extending accommodations and the cost-bearer's overall financial resources); see also Easley v. Snider, 36 F.3d 297, 305 (3rd Cir. 1994) (holding that a state-sponsored home nursing service was not required by the ADA to accommodate mentally disabled patients because doing so would impose an "undue and 
able to absorb greater implementation costs than smaller businesses. Yet, rather than create a minimum-employee threshold as a proxy for business size, and consequently a measurement of a business's ability to comply with antidiscrimination laws, ${ }^{180}$ this Essay proposes that courts weigh implementation costs against the resources of the relevant business on a caseby-case basis. Because these costs will vary based on a multitude of business-specific factors, a universal minimum-employee threshold does not serve as a useful proxy for a business's compliance capacity. Consider that a low-budget, couple-oriented bed-and-breakfast may simply need to omit the words "opposite-sex couples only" from their advertising materials. Meanwhile, a company like eHarmony may need to alter its website and quite possibly its compatibility test in order to provide access to same-sex couples. The burdens presented by these changes must be weighed against the companies' resources to determine whether the burdens are undue.

Third, in separate-but-equal cases, courts should consider the feasibility of implementing separate channels of access. For example, if HurryDate has no demand for gay and lesbian speed dating, it is unreasonable to require the service to designate part of its speed dating parties to same-sex matching, only to have no one show up. The costs associated with that move are unreasonable. However, if there is even a small demand for same-sex matching, HurryDate must accommodate the individuals seeking it, even if the service would incur financial loss, ${ }^{181}$ unless it does not have the resources to absorb the loss. If someone makes a prima facie case showing that HurryDate underservices the gay and lesbian community, the business has the burden of proving that it faced an unreasonable financial burden in providing separate channels of access.

\section{c. Averting Product Alterations}

Borrowing from the language of the ADA, some business establishments might protest that providing access to both opposite-sex and samesex couples requires them to fundamentally alter their products, and that averting such fundamental alterations is a bona fide business interest. This

perhaps impossible burden on the State, possibly jeopardizing the whole program ..."); Roberts $v$. Kindercare Learning Ctrs., Inc., 896 F. Supp. 921, 927 (D. Minn. 1995) (holding that a daycare center would be unduly burdened by accommodating a disabled child because it was "on a shoestring budget," lacked adequate personnel, and had a parent corporation that was just coming out of bankruptcy) (internal quotations omitted).

180. Some laws have taken this route. For example, Congress included a minimum-employee threshold in Title Vll, limiting the law's reach in order to protect small businesses from unreasonable implementation and litigation costs. See Jeffrey A. Mandell, Comment, The Procedural Posture of Minimum Employee Thresholds in Federal Antidiscrimination Statutes, 72 U. CHI. L. REv. 1047, 1063 (2005) (discussing the legislative history behind Title Vll's minimum-employee threshold).

181. Cf. McCabe v. Atchinson, Topeka \& Santa Fe Ry. Co., 235 U.S. 151, 161 (1914) (rejecting the argument that, under the pre-Brown separate-but-equal race regime, limited demand by blacks and its potential effect on profits justified providing luxury train cars for whites only). 
claim is weak because the ADA is distinguishable from the proposed law. ADA jurisprudence is unique in that it sets a particularly high bar for compliance. Unlike the proposed law, which only protects equal access, the ADA protects equal access and enjoyment. ${ }^{182}$ Although the language of the Civil Rights Act of 1964 also includes the words "equal enjoyment," the Supreme Court has suggested that, in the context of the Civil Rights Act, "enjoyment" is synonymous with "access." 183 This conflation, however, is not present in ADA jurisprudence. Because the ADA sets a higher bar for compliance, it also warrants a more expansive limiting principle. The ADA's expanded limiting principle does not transfer to the proposed law because the proposal only requires businesses to guarantee equal access.

The fundamental-alterations argument generally arises in ADA litigation when a disabled person has already gained access to an establishment but demands that the establishment be modified so she can derive equal utility. In one case, a disabled golf player, who had already gained access to a professional golf tournament, demanded the use of a golf cart in order to protect his enjoyment of the tournament. ${ }^{184}$ The court found that providing the plaintiff with cart privileges did not fundamentally alter the tournament. ${ }^{185}$ In contrast, a disabled hockey player, who already gained access to an ice hockey league, demanded that he be allowed a relative with him on the ice to direct his moves. ${ }^{186}$ In that case, the court held that, although the plaintiff required the presence of a relative on the ice to protect his enjoyment of the game, allowing the relative on the ice fundamentally altered the game. ${ }^{187}$

Unlike ADA jurisprudence, the proposed law creates only a right of access, not of enjoyment. Thus, to the degree that product alteration is necessary to provide access to both opposite-sex and same-sex couples, those alterations should be enforced, subject to the limits justified by undue burdens and compelled bisexuality. This principle is not new. Consider a hypothetical 1950s-themed diner. The diner might argue that it must racially segregate its seating in order to accurately emulate a diner from the 1950s. Accordingly, it wants to relegate black patrons to undesirable tables near the restrooms. In this case, access (to the diner's desirable tables) is intertwined with the product itself (a 1950s theme). To grant equal access to black patrons, the diner must desegregate. Compelling the diner to

182. 42 U.S.C. $\$ 12182$ (a) (2000) ("No individual shall be discriminated against on the basis of disability in the full and equal enjoyment of the goods, services, facilities, privileges, advantages, or accommodations of any place of public accommodation.") (emphasis added).

183. See supra note 130.

184. Martin v. PGA Tour, Inc., 994 F. Supp. 1242 (D. Or. 1998), aff'd 204 F.3d 994 (9th Cir. 2000) and 532 U.S. 661 (2001).

185. Id. at 1253.

186. Elitt v. U.S.A. Hockey, 922 F. Supp. 217 (E.D. Mo. 1996).

187. Id. at 224 . 
desegregate its seating modifies its product's hallmark-a fundamental component of the diner's business product. However, the diner may not use fundamental alterations to justify discrimination.

Similarly, attempts to avert product alterations do not justify discrimination in the couples context. In the case of eHarmony, access and product are also intertwined. A gay man qua gay man cannot use eHarmony because of the way eHarmony's product is currently fashioned. To use eHarmony, the gay man must adopt a pseudonymous heterosexual identity and use eHarmony to meet women. In order to match same-sex couples, eHarmony needs to change its website. Depending on the mechanics of its computerized matching program, a dating service like eHarmony might also need to change the program's algorithms. Looking beyond eHarmony, one can hypothesize the mechanics of an imaginary dating service, eDuet.

Hypothetical v.1: eDuet's compatibility program, originally created for opposite-sex matching, is directly applicable to same-sex matching. For example, the compatibility program might simply match partners based on complementary interests-interests in music, sports, religion, etc. eDuet can use this exact same test to match same-sex partners. eDuet would need only to discern its patrons' sexual orientation and run a filtering mechanism to prevent inadvertently compelling bisexuality by, for example, matching two straight men with complementary interests. ${ }^{188}$

Hypothetical v.2: It is possible that the compatibility program requires additional tweaking. The compatibility survey may contain questions applying only to certain types of couples. For example, say eDuet asks a stream of explicitly sexual questions regarding vaginal sex. Because gay men qua gay inen cannot answer these questions, eDuet needs to modify its compatibility survey either by letting gay men check off an "N/A" box or by coming up with an alternative survey altogether that matches gay male couples. ${ }^{189}$

At this point, I can imagine some readers' eyes widening in disapproval at the suggestion that eDuet needs to modify its compatibility test. One might argue that requiring an "N/A" box is like requiring Victoria's Secret to start stocking lingerie in men's sizes. But the Victoria's Secret analogy falls short. Requiring Victoria's Secret to change is objectionable, whereas requiring eDuet to change is not. In the case of Victoria's Secret, product and access are not intertwined. Even if Victoria's Secret does not reform, men qua men have access to the store: a man can walk into Victoria's Secret, buy a bra for himself to wear, walk out of the store, and call himself a man throughout that process. Conversely, a potential gay

188. On compelled bisexuality, see supra Part 111.B.2.a.

189. I should note that even eHarmony's 436-question survey does not contain any questions that are so clearly inapplicable to gay male couples. To my knowledge, eDuet is a hypothetical extreme. 
male couple qua gay male couple can never answer questions about how they prefer to perform vaginal sex with each other. In the case of eDuet, product and access are intertwined. In that sense, eDuet's sexually explicit compatibility program is more akin to the fifties diner than to Victoria's Secret. Unless the product is modified, access is denied. ${ }^{190}$

Certainly, eDuet can argue that developing a survey catering to gay men creates an undue burden. However, eDuet would need to prove it. Like eHarmony, eDuet can argue that it expended a great deal of resources studying heterosexual couples to create its existing compatibility program. ${ }^{191}$ However, that fact alone does not exempt eDuet from the proposed law. What if eDuet had studied only white couples? It would be equally objectionable if eDuet were to rely on that premise to justify barring all non-whites from accessing its dating service.

eDuet need not guarantee that its compatibility program is useful to gay men. It need only guarantee access. Perhaps eDuet's compatibility program-after adding all the "N/A" options-simply does a poor job of matching gay male couples. The question of whether gay men want to purchase a potentially useless service is for gay men to decide. Consider this analogy: an Asian-American woman with straight hair may find useless a hairstylist who specializes in relaxing African-American hair. It is one thing for the Asian-American woman to decide for herself that the stylist's services are useless to her. But it is another thing entirely for the stylist to hang a "Blacks Only" sign in his window.

As mentioned above, deciding not to purchase a useless product is empowering. The customer is exercising her freedom of autonomous decision-making. Excluding someone from that decision-making process inflicts injury. The excluded party is left to question why she was excluded, and human dignity is implicated. The Supreme Court reminds us that "deprivation of personal dignity ... surely accompanies denials of equal access . . ."192 Under that reasoning, businesses should be required to provide equal access, even in cases where access and product are intertwined, causing some businesses to alter their products.

190. One might raise gynecologists and sperm banks as examples of businesses in which access and product are intertwined. There is no way a man himself can use a gynecologist's services. Similarly there is no way a woman can donate to a sperm bank. Should the gynecologist and sperm bank be required to modify their services? They would likely be excused under most existing laws due to health and safety concerns. See supra note 141 and accompanying text. Also, one could argue that requiring the gynecologist to learn another medical specialization and rcquiring the sperm bank to develop eggdonor facilities would create undue burdens.

191. On eHarmony, see supra note 1.

192. Heart of Atlanta Motel, 379 U.S. at 250 (internal quotation marks to the Senate Commerce Committee speaking on the Civil Rights Act of 1964 omitted); see also Roberts $v$. United States Jaycees, 468 U.S. at 625 (1984) (holding that sex-based discrimination in public accommodations "deprives persons of their individual dignity and denies society the benefits of wide participation in political, economic, and cultural life"). 
Of course, an underlying assumption to the eDuet hypothetical is that eDuet has no cognizable constitutional claim to free expression or free religious exercise. eDuet would need to be more than a commercial service provider to make a successful claim under the First Amendment; ${ }^{193}$ it would need to be a membership organization or a religious group whose group identity hinges on objections to same-sex relationships. If the First Amendment is implicated, a court might balance couples' rights against group rights - the rights of religious groups and expressive associationsin the way that courts already balance individual rights against group rights. For example, in Boy Scouts of America v. Dale, ${ }^{194}$ the Boy Scouts' right to free expression trumped a gay scoutmaster's right to nondiscrimination. ${ }^{195}$ If eDuet were a membership organization using a heterosexual dating service to further its explicit mission of promoting heterosexuality, it is possible that compelling eDuet to alter its service would unconstitutionally compromise the message it seeks to spread. ${ }^{196}$

\section{IV}

\section{Conclusion: Public Accommodations and Beyond}

It seems that, at every turn, we are reminded of our sexual orientation. Oftentimes, this reminder comes in the form of an activity involving coupling. These reminders likely ring most loudly to sexual minorities. For example, two gay men who attend a ballroom dance lesson with some of

193. See Roberts v. United States Jaycees, 468 U.S. at 634 (O'Connor, J., concurring):

There are, of course, some constitutional proteetions of commercial speech-speech intended and used to promote a commercial transaction with the speaker. But the State is free to impose any rational regulation on the commercial transaction itself. The Constitution does not guarantee a right to choose employees, customers, suppliers, or those with whom one engages in simple commercial transactions, without restraint from the State.

194. 530 U.S. $640(2000)$.

195. Id. at 644. The Boy Scouts successfully argued that it "teaches that homosexual conduct is not morally straight," and that allowing gay men to serve as scoutmasters would compromise that message. See id. at 651 (internal quotations omitted).

196. Some human rights advocates may protest my endorsement of Dale. See Raju Chebium, High Court Allows Boy Scouts to Exclude Gays, CNN, June 28, 2000, http://archives.cnn.com/ 2000/LAW/06/28/scotus.gay.boyscouts.01 (quoting the Human Rights Campaign for calling Dale a "travesty of justice"). I agree that the Boy Scouts' discriminatory policy compromises the dignity of gay men. However, I believe that, while the government should generally proscribe sexual orientation discrimination, it should make rare exceptions for certain private organizations. By relegating these groups to an exception status, the government indirectly disapproves of their policies while respecting their group autonomy. In that manner, the Dale litigation marginalized the Boy Scouts and, consequently, the Boy Scouts suffered reduced public support. See Sheryl McCarthy, Boy Scouts' Victory on Gays Cuts Contribution Flow, NewsDAY, July 24, 2000, at A26. See also Katharine T. Bartlett, Only Girls Wear Barrettes: Dress and Appearance Standards, Community Norms, and Workplace Equality, 92 MicH. L. REv. 2541, 2576-79 (1994) (argning that, oftentimes, employers claiming Title VII's bona fide occupational qualification (BFOQ) effectively segregate themselves, leading social forces to mobilize against them). With that said, I believe the government should balance competing interests better by honoring Dale but disapproving of the Boy Scouts by rescinding from the organization any government support, such as the use of public schools for meetings. Amy Gutmann has argued for this balancing scheme in her book IDENTITY AND DEMOCRACY, at 107-08 (2003). 
their straight friends might feel singled out, forced to suppress their sexual orientation by dancing with women. These men are reminded that their sexual orientation extends beyond their bedroom doors. In another example, a group of friends attend a speed dating party together and, upon arrival, the sole lesbian in the group realizes that there is no table for same-sex matching. That lesbian is reminded that sexual orientation extends beyond bedroom doors.

These examples may seem trivial. Perhaps it is because, unlike marriage-which is purportedly a once-in-a-lifetime event-these situations occur more frequently, rendering them nothing particularly momentous. However, it is precisely that lack of special flavor, the regularity and ubiquity with which these examples arise, that makes them troubling. Every day, heteronormative presumptions in coupled activities affirm the sexual orientation of some people while suppressing the sexual orientation of others. Accordingly, some are able to develop their sexual identity with relative ease while others face obstacles-even pain and suffering. For that reason, it is imperative that lawmakers and jurists conceptualize sexual orientation antidiscrimination as more than an individual right. The time is ripe to think of sexual orientation antidiscrimination in terms of couples' rights and public recognition.

Public accommodations laws provide fertile ground for pursuing this goal. Many of these laws already protect against sexual orientation discrimination. The question becomes how to think of sexual orientation with regard to those laws. To ensure that regulations adequately protect against sexual orientation discrimination, we must ensure that they prohibit businesses from discriminating between opposite-sex and same-sex couples. This Essay proposed a preliminary model for achieving that end. Integrating same-sex couples into the couples-oriented market is likely to assuage sexual minorities' broader struggles because increasing the visibility of same-sex couples will diminish homophobia based on ignorance. ${ }^{197}$

This Essay can serve as a springboard for couples' rights analyses beyond the context of public accommodations law. In other areas of jurisprudence, commentators have asserted that restricting same-sex relationships is not necessarily discrimination on the basis of sexual orientation. ${ }^{198}$ Opponents of this position often respond with under-theorized arguments. ${ }^{199}$ This Essay provides an analytical theory to support those arguments.

Consider the Lawrence $v$. Texas litigation, in which the Texas court of appeals stated that Texas's same-sex sodomy ban was neutral because "[p]ersons having a predominately heterosexual inclination may sometimes

197. On the relationship between ignorance and homophobia, see supra note 31 .

198. See, e.g., infra notes 200,202 , and accompanying text.

199. See, e.g., infra notes 201 and accompanying text. 
engage in homosexual conduct. Thus, the statute's proscription applies, facially at least, without respect to a defendant's sexual orientation." ${ }^{200}$ In her concurring Supreme Court opinion, Justice O'Connor disagreed, arguing that the statute was not neutral because same-sex sodomy is "closely correlated" to being homosexual. ${ }^{201}$ O'Connor's conclusion is buttressed by an analysis in the couples' rights paradigm: the Texas statute is not neutral with regard to sexual orientation because only same-sex couples can violate the Iaw. By its very definition, the law precludes finding that any opposite-sex couple committed the proscribed "crime."

Consider also same-sex marriage. There is disagreement over whether same-sex marriage bans really amount to sexual orientation discrimination since whether an individual can marry a woman arguably does not turn on that individual's sexual orientation (gay, straight, and bisexual men can all marry women); the discrimination arguably turns on sex (only women cannot marry other women) ${ }^{202}$ In a couples' rights paradigm, the key question is not whether an individual may wed, but whether two individuals-that is, a couple - may wed each other ${ }^{203}$ The couples' rights inquiry focuses on the fact that a gay couple can never get married, even though a gay individual can. By shifting the inquiry from the gay individual to the gay couple, moving from the individualist paradigm to the couples' rights paradigm captures why same-sex marriage bans indeed constitute sexual orientation discrimination.

The couples' rights paradigm gives moral status to the couple as a collective entity that cannot be reduced to the sum of its constituent parts. Because this paradigm gives moral status to the couple, it suggests that disparate treatment of couples is troubling even when disparate treatment of individuals is absent-and Equal Protection jurisprudence should take that into consideration.

While I have sketched possible implications that the couples' rights paradigm has outside the public accommodations context, my sketches here are by no means comprehensive or conclusive. I offer them simply to

200. Lawrence v. State, 41 S.W.3d. 349, 353 (2001), rev'd, 539 U.S. 558 (2003).

201. Lawrence, 539 U.S. at 583 (O'Connor, J., concurring). O'Connor reasoned that same-sex sodomy is "closely correlated" to being homosexual because it is the "conduct that defines the class." Id. (quoting Romer v. Evans, 517 U.S. 620, 641 (1994) (Scalia, J., dissenting)).

202. Compare Goodridge v. Dep't of Pub. Health, 798 N.E.2d 941, 958 (Mass. 2003) (holding that Massachusetts' proscription of same-sex marriage unconstitutionally "deprives individuals of access to an institution of fundamental legal, personal, and social significance-the institution of marriagebecause of a single trait ... sexual orientation..."), with Baehr v. Lewin, 852 P.2d 44, 52 nn.11-12 (Haw. 1993) (suggesting that Hawaii's proscription of same-sex marriage discriminated on the basis of sex, but not on the basis of sexual orientation).

203. Some foreign courts implicitly adopted the couples' rights paradigm when they held that barring same-sex couples from marriage is unconstitutional. See supra note 91 . In contrast, the United States Supreme Court generally speaks of the freedom to marry as an individual right. See Loving v. Virginia, 388 U.S. 1, 12 (1967) ("the freedom to marry or not to marry ... resides with the individual ..."). 
highlight the potentially far-reaching effects of a paradigm shift and to invite future discourse on aggregate rights in the sexual orientation context. 